DEPARTMENT OF THE INTERIOR

U.S. GEOLOGICAL SURVEY

\title{
Modern palynomorph and weather census data from the U.S. Atlantic Coast (Continental Margin Program samples and selected NOAA weather stations)
}

Ronald J. Litwin and Victoria A. S. Andrle

U.S. Geological Survey, Reston, VA 22092

Open-File Report 92- 263

This report is preliminary and has not been reviewed for conformity with U.S. Geological Survey editorial standards 


\section{Modern palynomorph and weather census data from the U.S. Atlantic Coast (Continental Margin Program samples and selected NOAA weather stations}

Ronald J. Litwin and Victoria A.S. Andrle, MS 970, U.S. Geological Survey, Reston, VA

\section{INTRODUCTION}

This report is a preliminary summary of palynomorph census data obtained from 25 modern nearshore marine bottom samples, selected along a northeast-southwest oriented transect, which extends from the Gulf of Maine (ME) to Key West (FL). It also includes a parallel transect of average summer/winter/annual temperature data and average annual precipitation data, compiled from the NOAA database, for 93 coastal and near-coastal weather stations selected for this study. Together these two datasets form a baseline modem analogue for a reconnaissance of Pliocene nearshore marine sediments, deposited during a time interval of global high-sea level, and now exposed on and along the U.S. Atlantic Coastal Plain from Martha's Vineyard (MA) to Sarasota (FL). This research is part of the U.S. Geological Survey's program to study the climatic and oceanographic conditions of the Pliocene, and is one of a series of open-file reports which makes available the datasets on which our multiple analyses are being done. The multivariate analyses and comparison of this shallow marine pollen dataset with an analogous Pliocene shallow marine pollen dataset will be presented elsewhere.

\section{MATERIALS AND METHODS}

The modern shallow marine bottom samples from which the palynomorphs were recovered and identified are splits from the Continental Margin Program (CMP) sample dataset housed at Woods Hole Oceanographic Institute (Hathaway, 1971). The station localities for the shallow marine transect are presented in Figure 1. 


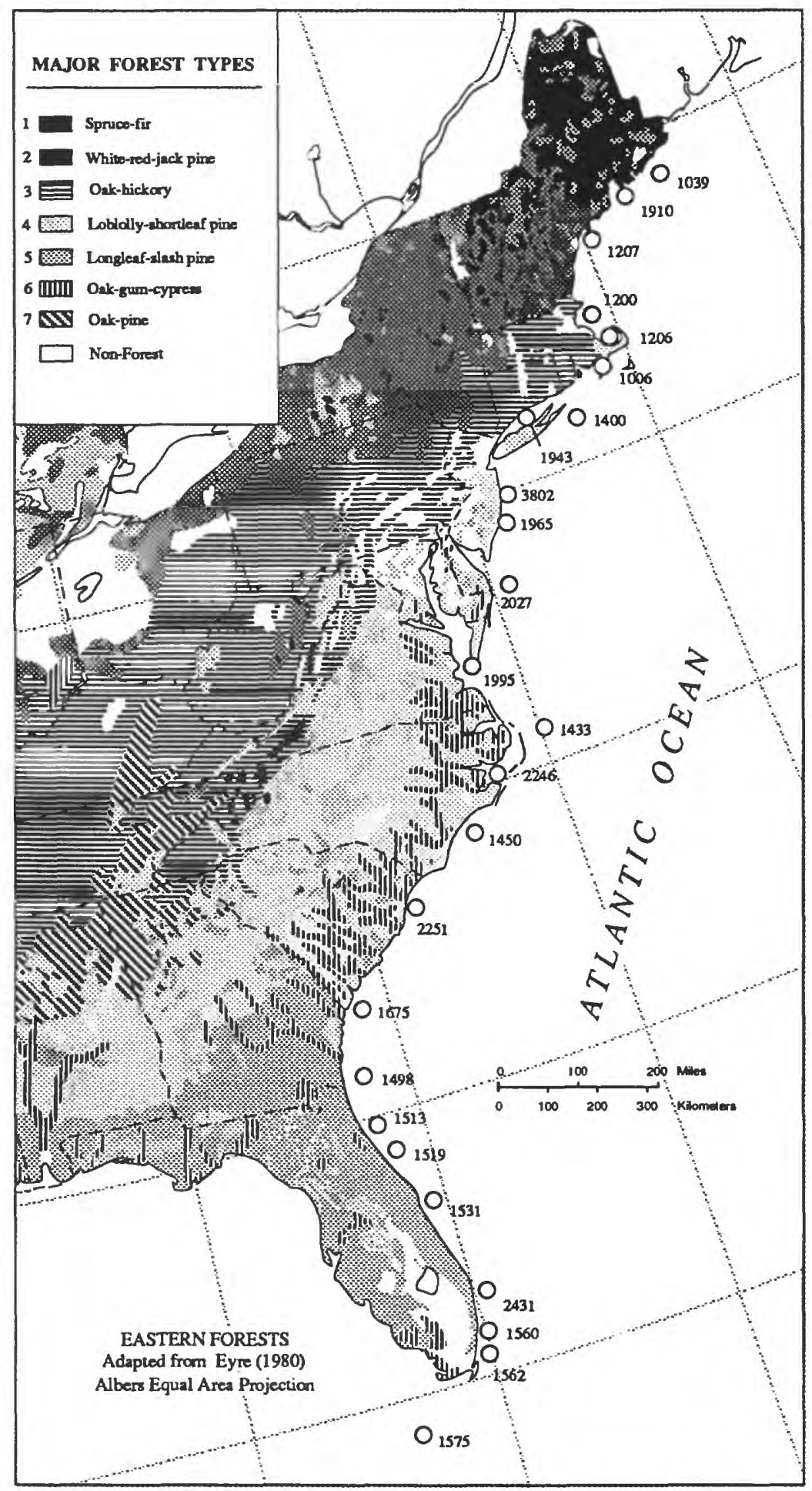

FIGURE 1. CONTINENTAL MARGIN PROGRAM TRANSECT STATIONS AND MAJOR FOREST TYPES OF THE EASTERN UNITED STATES 
The weather data was compiled from raw data presented in the National Oceanographic and Atmospheric Administration's Climatological Data Annual Summary (NOAA-CDAS) for coastal portions of Maine, New Hampshire, Massachusetts, Rhode Island, Connecticut, New York, New Jersey, Delaware, Maryland, Virginia, North Carolina, South Carolina, Georgia, and Florida for the years 1981-1990. This transect of 93 weather stations was selected by us from stations located at or near the Atlantic Coast (Figure 2A-2B).

\section{CONTINENTAL MARGIN PROGRAM PALYNOMORPH DATASET}

Twenty-five marine sediment ("bottom") samples (Fig. 1) were selected as acceptable stations for our transect, from an Atlantic Coast database of over 3500 shallow marine sediment samples. Only these samples, out of an original selection of approximately forty samples, met sedimentological and geographical prerequisites necessary for this study. Our final modern marine dataset was limited to those samples which contained an unoxidized silt fraction (the sediment most likely to contain preserved palynomorphs), which were deposited in a shallow marine environment, and which produced sufficient identifiable palynomorphs ( 300 specimens minimum) for pollen analyses. Of these twenty-five samples, twenty-three form the best analogue dataset for comparison to the nearshore marine Pliocene transect currently under study.

Many of these samples had a high clay fraction and did not contain abundant pollen. Obtaining an effective separation of the organic debris (pollen, spores, and plant fragments) from the clay therefore was critical for sufficient pollen recovery. Processing procedures for these sediment splits are summarized here. Approximately 20-50 grams of sediment were processed per station, depending upon availability. The dry samples were weighed, then treated with $20 \% \mathrm{HCl}$ for $1-2$ days to decalcify the sediment. No tracers (Lycopodium) were added. The samples were decanted and rinsed in DI water repeatedly until the sediment-water suspension was neutral. Wet mounts were made of each sample, 


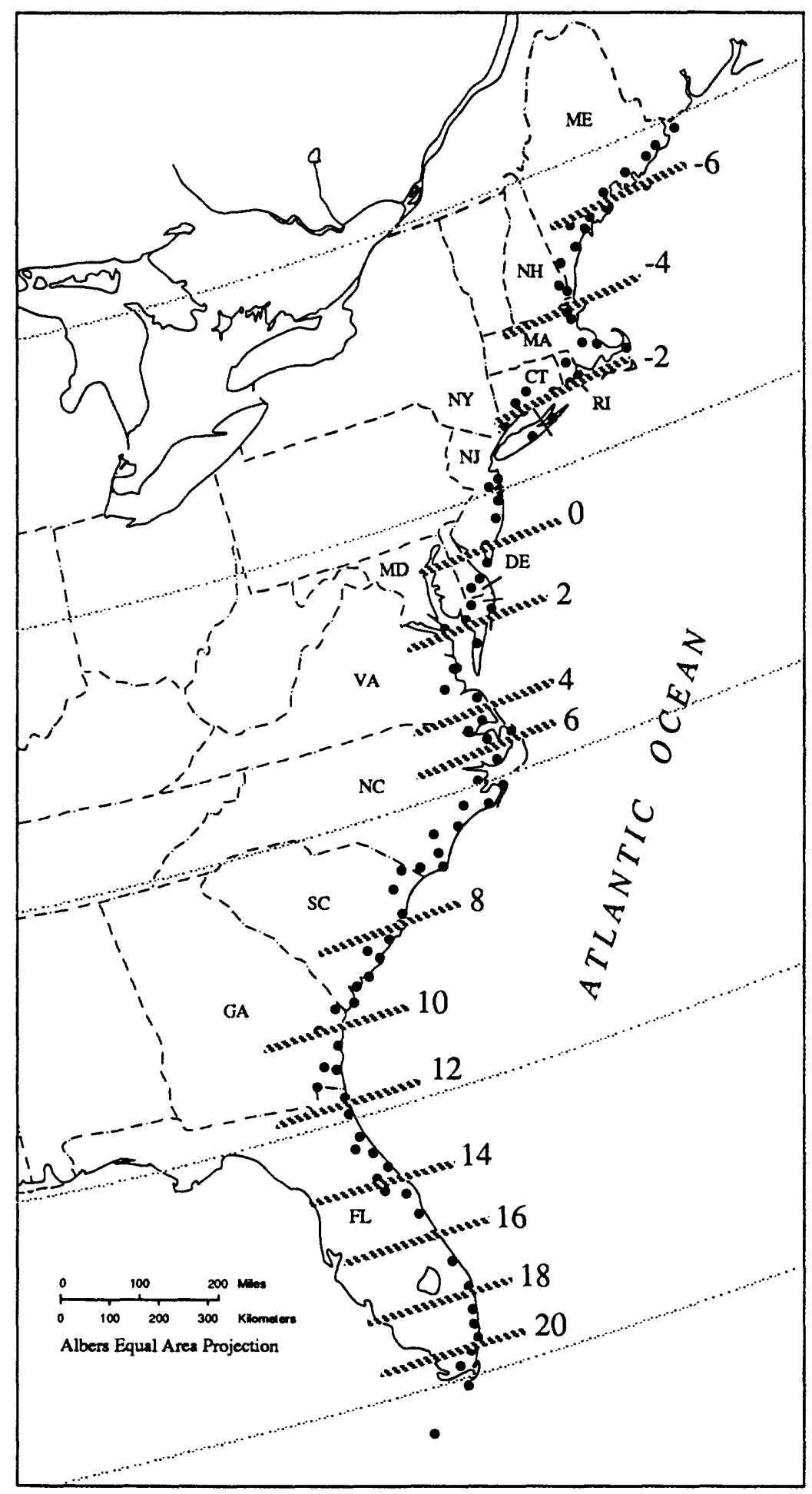

FIGURE 2A. NOAA CLIMATE TRANSECT COVERAGE AVERAGE JANUARY ISOTHERMS (C $\left.{ }^{0}\right)$ 1981-1990 


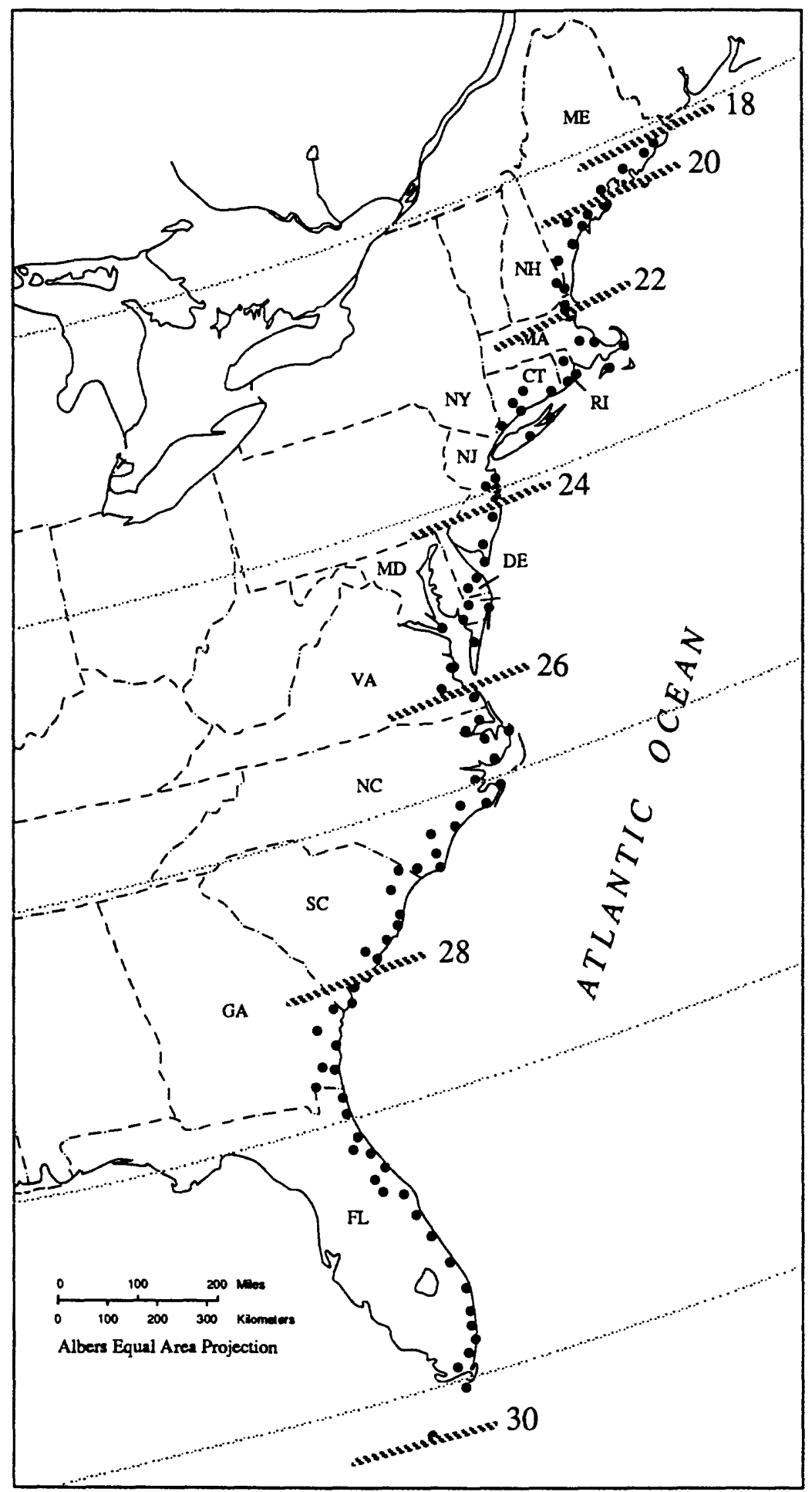

FIGURE 2B. NOAA CLIMATE TRANSECT COVERAGE: AVERAGE JULY ISOTHERMS $\left(C^{0}\right)$ 1981-1990 
and those samples which were not disaggregated or which had abundant clay were treated with $52 \%$ HF (in a fume hood) until the mineral fraction of each sample was disaggregated. The samples were siphoned and rinsed in DI water until neutral, and additional strew slides were made to check for relative abundance of residual clay. Those samples which were reduced to silt- and sand-sized particles were decanted, centrifuged, rinsed in $2 \% \mathrm{HCl}$, centrifuged, decanted, and put into an aqueous solution of zinc chloride (adjusted to 2.0 specific gravity). Those samples which still contained abundant clay after $\mathrm{HCl}$ and $\mathrm{HF}$ treatment had the clay fraction removed before being rinsed in dilute $\mathrm{HCl}$ and placed into zinc chloride. Clay removal was accomplished by repeated slow and brief centrifugation of these muds in a dilute low-sudsing detergent solution. The clay (and part of the organic debris) preferentially was held in suspension after centrifugation, and was decanted into a large beaker (one beaker for each sample). More soap solution was added, the sediment again centrifuged, and the supernatent was decanted into the large beaker, this process was repeated until the supernatent was clear after centrifugation (i.e., most of the clay had been transferred to the beaker). The silt and sand fraction from these samples was rinsed and centrifuged in water several times, rinsed in $2 \% \mathrm{HCl}$, centrifuged, drained, and treated with zinc chloride ( $2.0 \mathrm{sp}$. gr., as above). The zinc chloride-sediment suspension was centrifuged in $50 \mathrm{ml}$ tubes for 20 minutes @ 800 rpm, then @ 2000 rpm for 10 minutes. The pollen fraction separated from the mineral fraction in the heavy liquid and was pipetted off of the top of the zinc chloride column into a $15 \mathrm{ml}$ centrifuge tube. At this point the clay-rich supernatant was vacuum-filtered through an $8 \mu \mathrm{m}$ nylon filter to recover suspended palynomorphs from the soap decant. The palynomorphs were rinsed off the nylon filter with water and combined with those palynomorphs which were recovered from the heavy liquid treatment. The recombined palynomorph fraction for each sample was rinsed in DI water, centrifuged, and drained. Melted glycerin jelly was added to the drained palynomorph fraction and permanent microscope slide mounts were made.

Census counts of 300 specimens were made from each sample, for a total dataset of 7500 specimens. 
Some of these samples contained enough pollen that only several traverses across the microscope slide were necessary to identify 300 grains. Those samples which produced fewer than 300 specimens were discarded as candidate study sites for this transect. Sixty taxa and census categories (combinations of taxa) were identified from these samples. Conifer pollen frequently was encountered as broken specimens in these preparations. We have addressed this problem by counting broken specimens (isolated sacci) as half-specimens (and therefore have not counted isolated conifer corpi) in order to keep our counts consistent. This conifer subtotal then was added to the number of complete conifer pollen grains for a final total. For purposes of this study, pollen identifications were made to the generic level. In several cases identifications were feasible only to family level. These taxa were coded in the census database as noted below in Table 1. Palynomorph census figures are presented in Table 2. The original preparations from which these census data were compiled are reposited in the Pliocene Reconstruction, Interpretation, and Synoptic Mapping (PRISM) collections database at the U.S. Geological Survey, Reston, VA.

\section{NOAA-CDAS DATABASE}

One hundred weather stations were selected from coastal and near-coastal sites along the U.S. Atlantic Coast to establish a baseline for average winter, summer, and annual temperatures and annual rainfall latitudinally along the pollen transect. These temperature and precipitation data were compiled to form a climatic data transect extending from northern Maine to the Florida Keys (Figure 2, Table 3). Average temperatures and isotherms were compiled for January (winter) and July (summer) for the 1981-1990 ten year interval. February and August temperatures also were compiled and plotted to permit comparison to estimates of Atlantic Ocean surface and bottom water temperatures for the middle Pliocene, recently made on the basis planktic foraminfera and ostracodes (Cronin and Dowsett, 1990; Dowsett and Poore, 1990). 


\section{TABLE 1. CENSUS CODES AND IDENTIFICATION CATEGORIES}

CODE GENUS (FAMILY) COMMON NAME

ABIES Abies firs

ACER Acer maples

ALNUS Alnus alders

AMBRO Ambrosia ragweed

ARTEM Artemesia sage

BETUL Betula birches

BOTRM Botrychium fem

BOTRS Botryococcus alga

CARYA Carya hickory

CASTA Castanea chestnut

CELTI Celtis hackberry

CH-AM + Chenopodiaceae $\begin{aligned} & \text { goosefoot and } \\ & \text { pigweed families }\end{aligned}$

COMPO Compositae daisy family

CORNU Cornus dogwood

CORYL Corylus hazelnuts

CYPER Cyperaceae sedge

EPHED Ephedra ephedra

ERICA Ericaceae heaths, laurels

FAGUS Fagus beech

FRAXI Fraxinus ash

GALIU Galium bedstraw (licorice)

GLEDI Gleditsia honey locust

GRAMI Gramineae grasses

ILEX Ilex holly

JUGLA Juglans walnut

LARIX Larix larch

LIQUI Liquidambar sweetgum

LYCOP Lycopodium clubmosses

MAGNO Magnolia magnolia

MENYA Menyanthes bog plants (Family

MYRIC Myrica
CODE GENUS (FAMILY) COMMON NAME

MYRIO Myriophyllum submerged aquatics

NYMPH Nymphaceae water lilies

NYSSA Nyssa water gum, cotton gum

OSMUN Osmunda fern

OS-CA Ostrya/Carpinus hophornbeam/hornbeam

PALMA Palmae palms, palmettos

PICEA Picea spruce

PINUS Pinus pines

PLANE Planera water elms

PLATA Platanus sycamores

POLYG Polyganum buckwheat (smartweed)

POPUL Populus poplar

PRUNU Prunus cherry, plum

QUER Quercus oak

RUBUS Rubus raspberry

SALIX Salix willow

SAMBU Sambucus elderberry

SAO ferns (monolete)

SARCO Sarcobatus greasewood

SCO ferns (trilete)

SPHAG Sphagnum mosses

Taxodiaceae-

TCT Cupressaceae- cypresses, cedars, junipers Taxaceae

TILIA Tilia basswood (linden)

TSUGA Tsuga hemlock

ULMUS Ulmus elms

UNKNO unknown

VITIS Vitis grape 


\section{DISCUSSION}

The relative abundance of the most common taxa preserved in modern shallow marine bottom sediments appears to approximate the major vegetational trends established from terrestrial pollen data along the Atlantic Coast moderately well (Figure 3). The latitudes along the coast at which an individual taxon (in both the continental and marine pollen records) is found in greatest abundance appears to be representative of its maximum occurrence in the onshore vegetational assemblage. The raw data for selected taxa or census categories from the CMP transect stations also show several strongly developed but localized perturbations superimposed on these regional trends. Several of these perturbations appear to be caused by proximity to major river discharge, such as those recorded at stations 1675 and 2027 (Figure 4A). Seasonal pollination ("bloom" effects) also may be a factor, and could alter the regional vegetational pollen signature temporarily. Once these local effects are considered, and the transect sample coverage is averaged with latitude (Figure 4B), the overall pollen assemblage trend appears strongly representative of the five major forest types noted by Eyre (1980) which exist (with gradation) between $46^{\circ}-26^{\circ}$ north latitude along the U.S. Atlantic Coast. These forest types, from north to south, are: 1) Spruce-Fir (Picea-Abies), 2) White Pine-Red Pine-Jack Pine (Pinus strobus- P. resinosa- $P$. banksiana), 3) Oak-Hickory (Quercus- Carya), 4) Loblolly Pine-Shortleaf Pine (Pinus taeda- P. echinata), and 5) Longleaf Pine-Slash Pine (Pinus palustris- P. elliotti). A sixth type, Oak-GumCypress (Quercus- Nyssa-Taxodium) is widely established in middle to low latitudes, but restricted to river drainages inland to the Fall Line.

It is important to note that several of these major forest zones are characterized by more than one species of pine (Pinus). The species within this genus are not easily identified or discriminated solely on the basis of their pollen morphology. However, the pollen spectra in the shallow marine record, including the pine pollen spectrum, correlates positively with trends in continental pollen records at similar latitudes (see Figure 3, after Deicourt et al. (1984) and Bartlein et al. (1986)). 


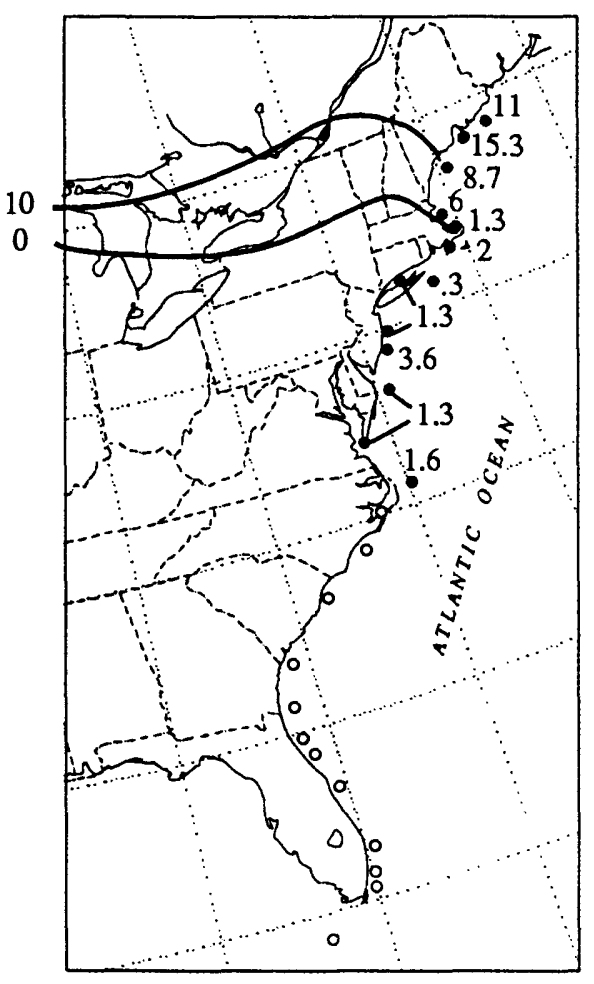

FIGURE 3A. PERCENT Picea

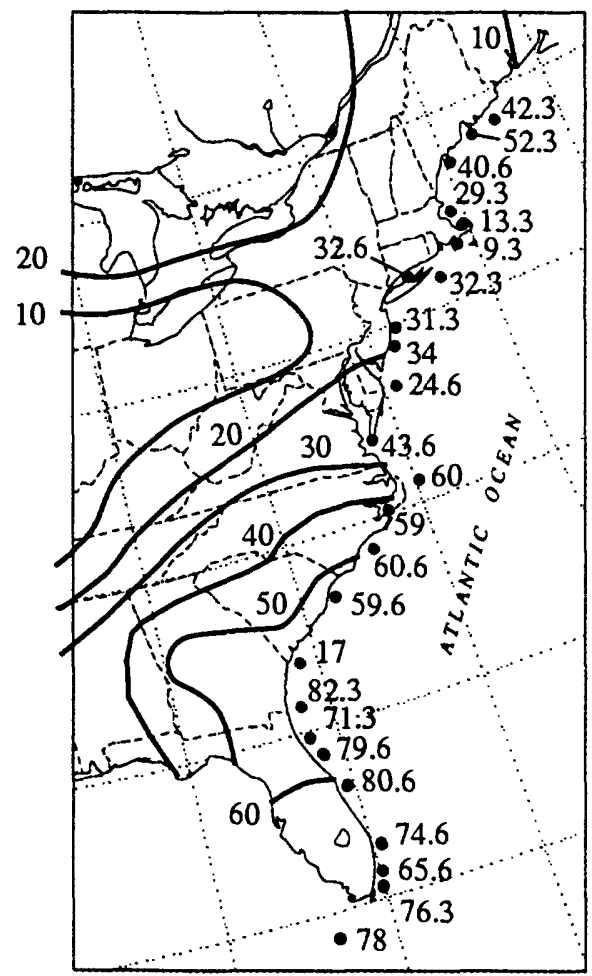

FIGURE 3C. PERCENT Pinus

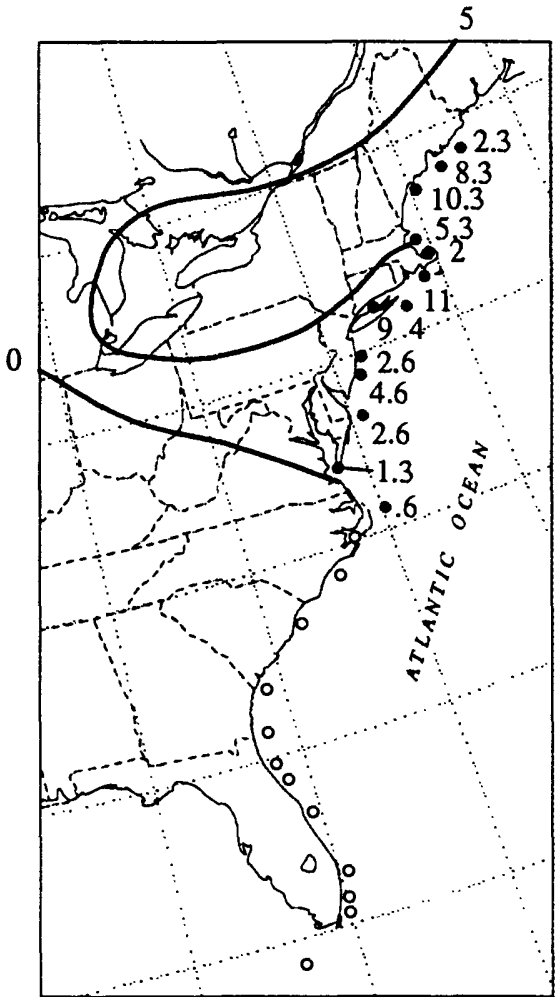

FIGURE 3B. PERCENT Tsuga

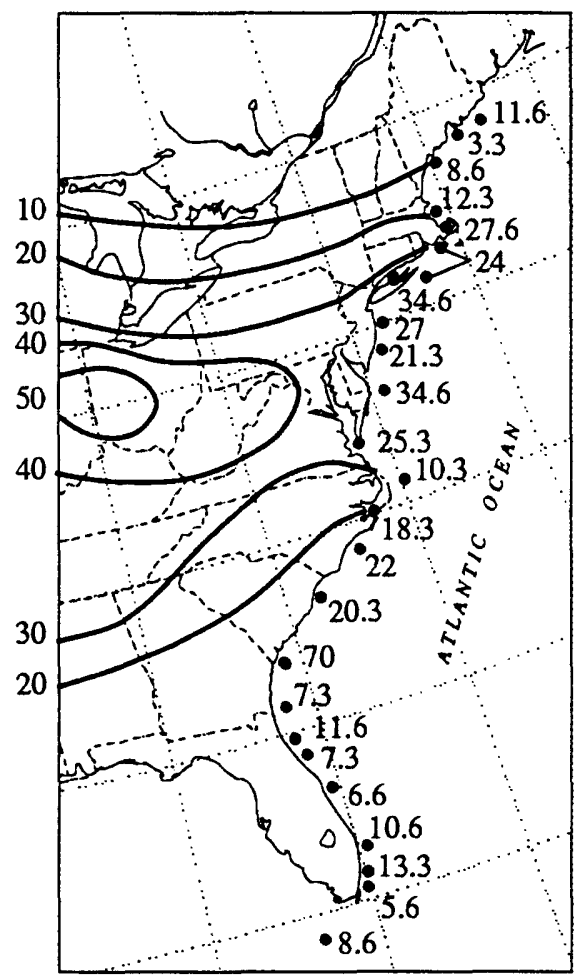

FIGURE 3D. PERCENT Quercus

FIGURE 3. COMPARISON OF CONTINENTAL POLLEN ISOPOLLS WITH POLLEN PERCENTAGES IN MODERN SHALLOW MARINE RECORD. ISOPOLLS FROM BARTLEIN ET AL. (1986). (OPEN CIRCLE DENOTES ABSENCE OF TAXON AT GIVEN CMP STATION) 


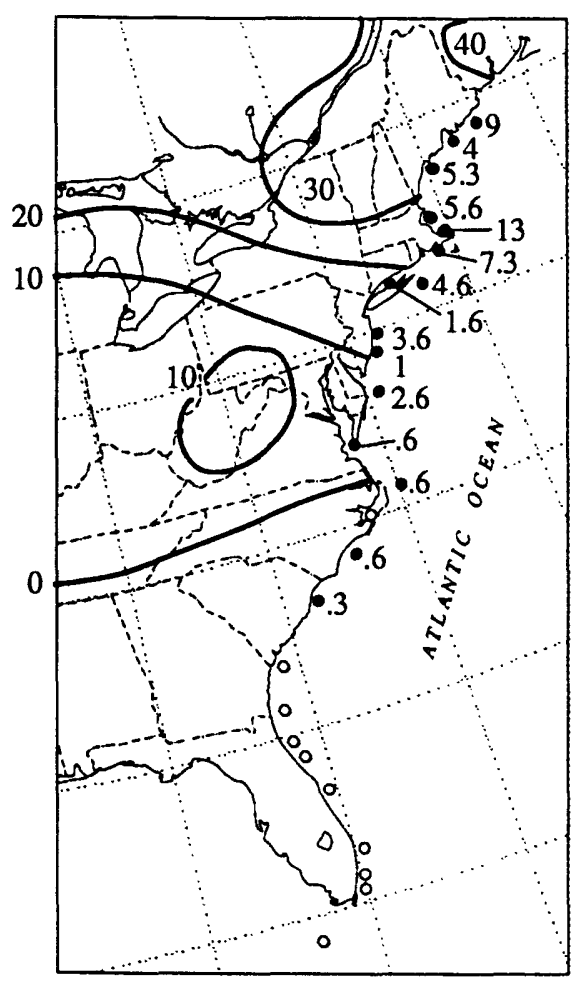

FIGURE,3E. PERCENT Betula

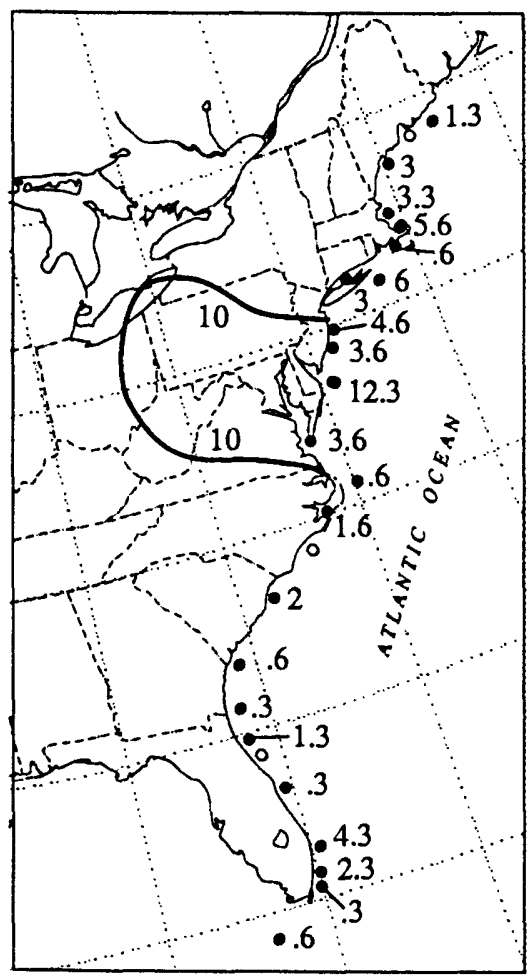

FIGURE 3G. PERCENT PRAIRIE FORBS

(Artemesia + Compositae +

Chenopodiaceae + Amaranthaceae)

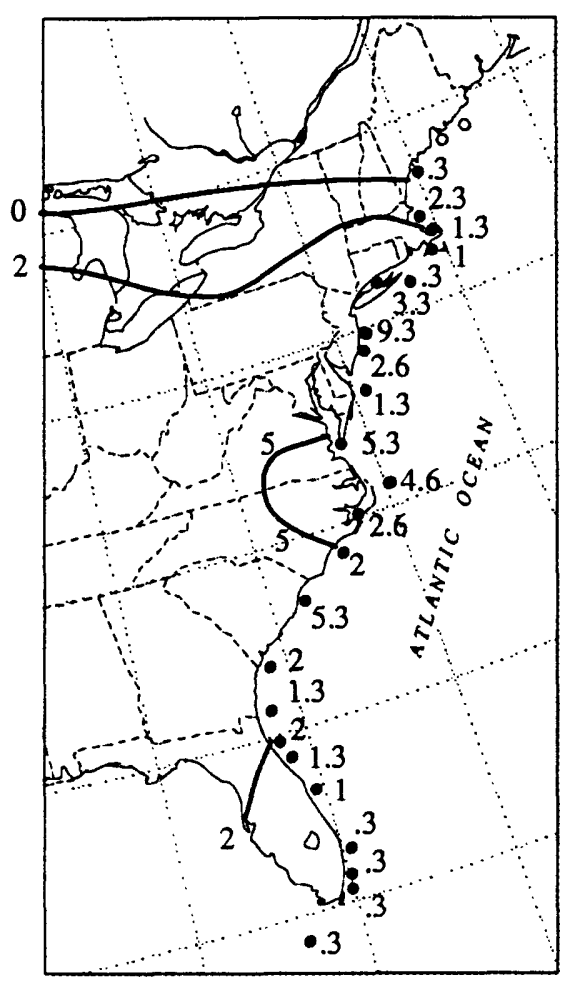

FIGURE 3F. PERCENT Carya

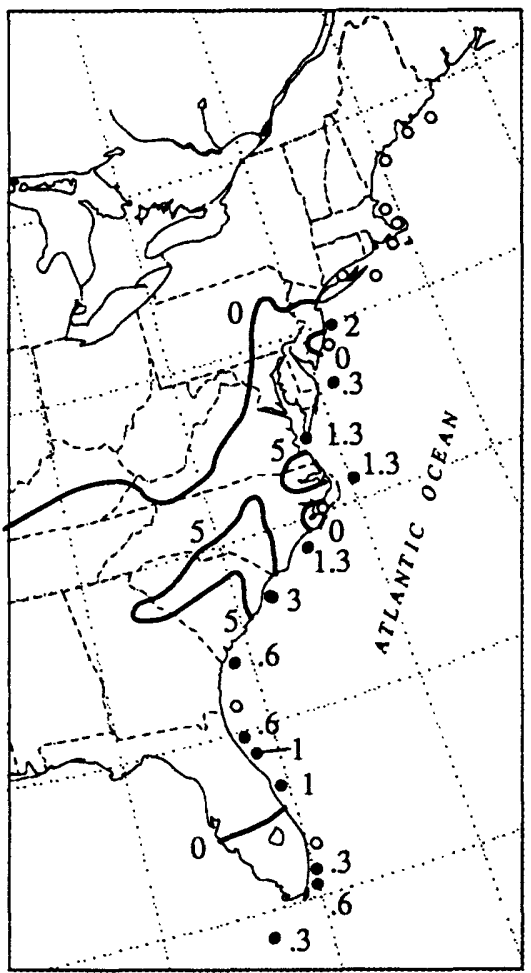

FIGURE 3H. PERCENT Liquidambar 


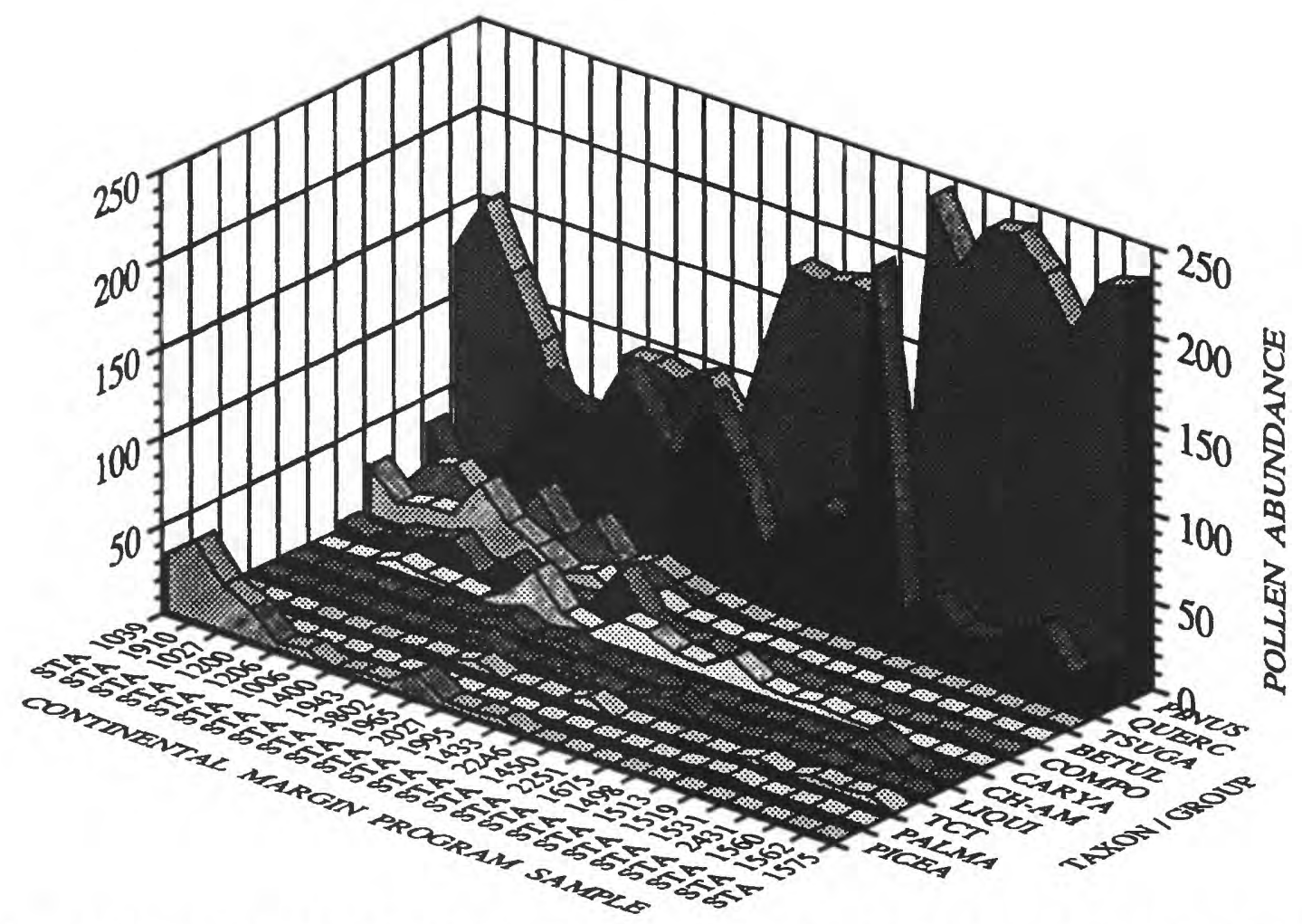

FIGURE 4A. PLOT OF ABUNDANCE OF SELECTED TAXA FOR ALL MODERN MARINE SITES

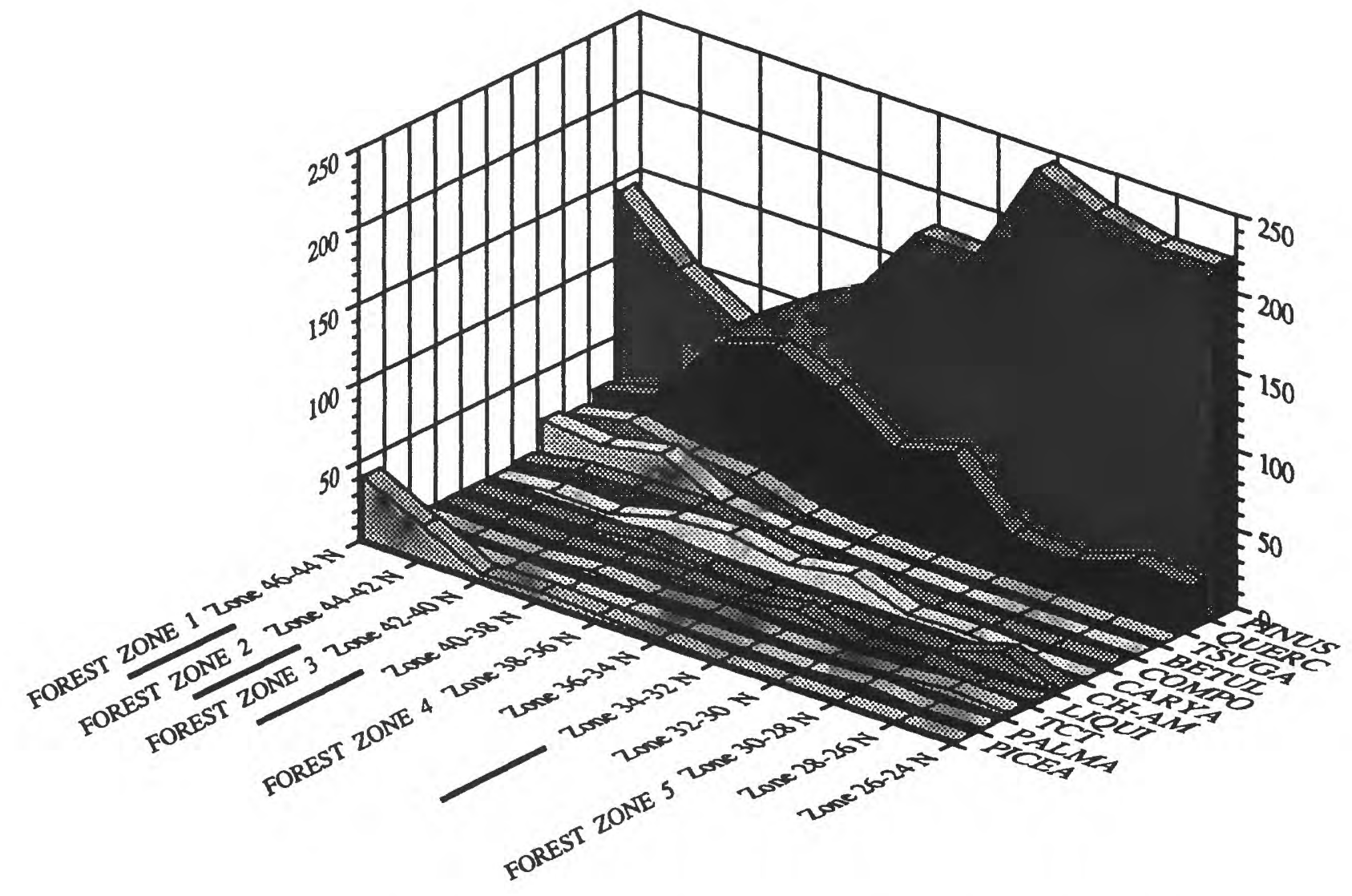

FIGURE 4B. PLOT OF SELECTED TAXA (MODERN) AVERAGED FOR LATTTUDE 
The pollen maxima for Picea, Tsuga, Betula, Quercus, Carya, and Pinus are very similar latitudinally with respect to the continental and marine records (but are not consistent quantitatively). For example, some taxa (e.g., Pinus) are two to four times more abundant in shallow marine sediments than in continental sediments, while others (e.g., Betula) appear to be underrepresented by a factor of two to three in the marine record.

Although arboreal pollen is the principal assemblage component in these samples, it is not the only useful palynological component in the shallow marine record. Herbaceous pollen taxa in the marine record also appear to respond both qualitatively and quantitatively to vegetational trends along the coast. For example, the presence of the Everglades (approximately $26^{\circ}-24^{\circ} \mathrm{N}$ latitude) is indicated by a localized influx of nonarboreal pollen at marine stations 2431, 1560, and 1562 (Fig. 4B). Additionally, the pollen maximum for "prairie-forbs" (=Compositae + Chenopodiacae + Amaranthaceae + Artemesia), as defined by Bartlein et al. (1986), is coincident for the continental and nearshore marine pollen record.

Finally, before accurate palynological analyses of the shallow marine record can be made it also is important to determine the degree to which Atlantic longshore currents alter and/or displace the shallow marine pollen record relative to the pollen record (and actual forest zones) onshore. Our initial comparisons of the major forest trends, the continental pollen record, and the Atlantic Coastal Plain vegetational zones suggests that southerly displacement of the marine pollen assemblages is minimal (Figures 1, 3, and 4). This effect is important to assess because it is relevant to an accurate interpretation of the Pliocene shallow marine pollen record, our primary objective.

\section{PRELIMINARY CONCLUSIONS}

Qualitative comparison between the continental pollen record and the shallow marine pollen record (this 
study) suggests the following: 1.) The nearshore marine record is more closely representative of onshore regional vegetational trends than of localized trends, although local trends can be recognized, 2.) the predominantly southerly longshore and shelf currents along the U.S. Atlantic Coast do not appear to have a noticeable effect on the southerly displacement of the marine pollen record relative to modern continental (onshore) records, 3.) some pollen taxa (e.g., Pinus) clearly are overrepresented in the shallow marine record, whereas others (e.g., Betula) appear to be underrepresented, and 4.) when local biasing effects (such as major river discharge) are taken into consideration, nearshore marine pollen assemblages appear to be good approximate indicators of latitudinally-similar continental pollen trends and regional forest assemblages.

\section{ACKNOWLEDGEMENTS}

The authors acknowledge with gratitude the following: Thomas Cronin (USGS, Reston) for project support and helpful discussion, John Schlee (USGS, Woods Hole) for providing sample splits from the CMP dataset, Robert S. Thompson and Thomas A. Ager (USGS, Denver) for helpful discussion and loan of slide reference material for pollen identification, Debra A. Willard (USGS, Reston) for helpful discussion and critical review of this report, and Nancy J. Durika (USGS, Reston) for assistance in sample processing and drafting.

\section{REFERENCES}

Bartlein, P.J., Prentice, I.C., and Webb, T., III, 1986, Climatic response surfaces from pollen data for some eastern North American taxa: Journal of Biogeography, v. 13, pp. 35-57.

Cronin, T.M., and Dowsett, H.J., 1990. A quantitative micropaleontologic method for shallow marine paleoclimatology: application to Pliocene deposits of the western North Atlantic Ocean: Marine Micropaleontology, v. 16, pp. 117-147.

Delcourt, P.A., Delcourt, H.R., and Webb, T.,III, 1984. Atlas of mapped distributions of dominance and 
modem pollen percentages for important tree taxa of eastem North America: Contribution Series 14, American Association of Stratigraphic Palynologists Foundation, $131 \mathrm{p}$.

Dowsett, H. J., and Poore, R.Z., 1990. A new planktic foraminifer transfer function for estimating Pliocene-Recent paleoceanographic conditions in the North Atlantic: Marine Micropaleontology, v. 16 , pp. 1-23.

Eyre, E.F. (ed.), 1980. Forest Cover Types of the United States and Canada. Society of American Foresters, Washington, D.C., 148 p.

Hathaway, J.C., (ed.), 1971. Data file: Continental Margin Program, Atlantic Coast of the United States. Volume 2. Sample Collection and analytical data. Technical Report 71-15, Woods Hole Oceanographic Institution.

National Oceanographic and Atmospheric Administration, 1981-1990a. Climatological data annual summary. New England, v. 93, no. 13 - v. 102 , no. 13 .

National Oceanographic and Atmospheric Administration, 1981-1990b. Climatological data annual summary. New York, vol. 93, no. 13 - vol. 102, no. 13.

National Oceanographic and Atmospheric Administration, 1981-1990c. Climatological data annual summary. New Jersey, vol. 86, no. 13 - vol. 95, no. 13.

National Oceanographic and Atmospheric Administration, 1981-1990d. Climatological data annual summary. Maryland and Delaware, vol. 85, no. 13 - vol. 94, no. 13.

National Oceanographic and Atmospheric Administration, 1981-1990e. Climatological data annual summary. Virginia, vol. 91 , no. 13 - vol. 100, no. 13.

National Oceanographic and Atmospheric Administration, 1981-1990f. Climatological data annual summary. North Carolina, vol. 86, no. 13 - vol. 95, no. 13.

National Oceanographic and Atmospheric Administration, 1981-1990g. Climatological data annual summary. South Carolina, vol. 84, no. 13 - vol. 93, no. 13.

National Oceanographic and Atmospheric Administration, 1981-1990h. Climatological data annual 
summary. Georgia, vol. 85 , no. 13 - vol. 94 , no. 13 .

National Oceanographic and Atmospheric Administration, 1981-1990i. Climatological data annual summary. Florida, vol. 85 , no. 13 - vol. 94 , no. 13. 
세 $000000000-00-1-00000000$

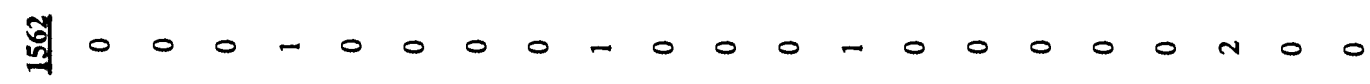

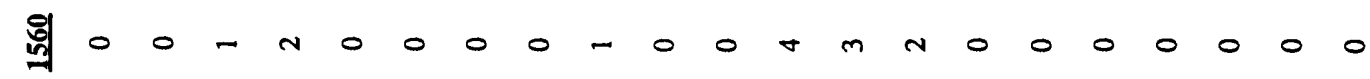

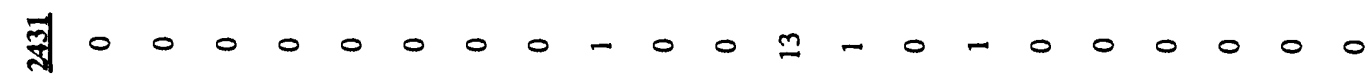
武 $00-00000 \mathrm{~m} 00-00 \mathrm{~m} 000000$

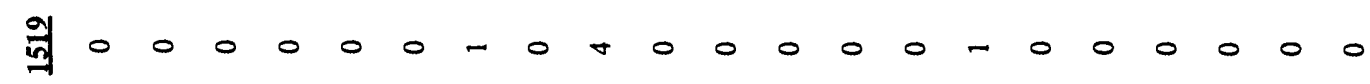

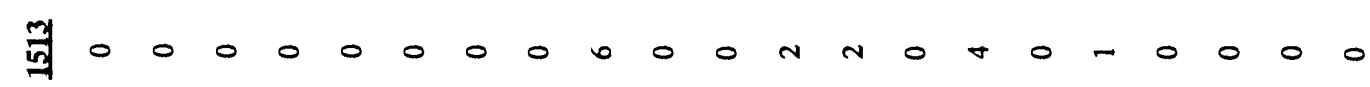
行 $000000000+00-0000000000$

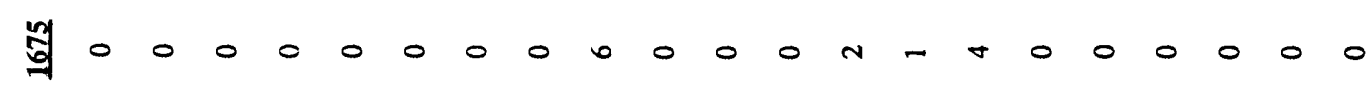

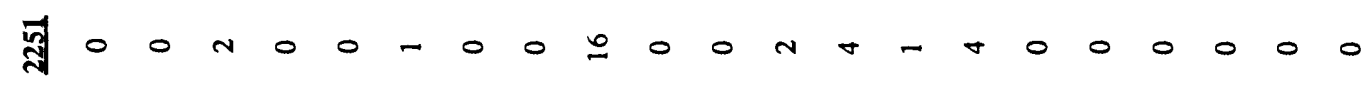

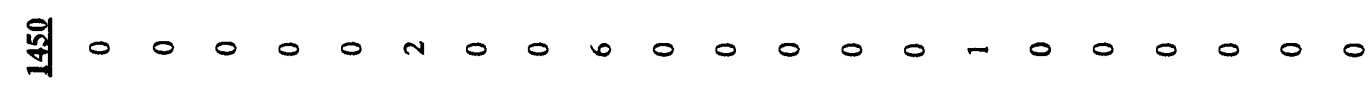

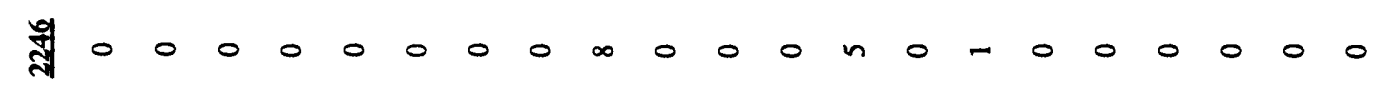

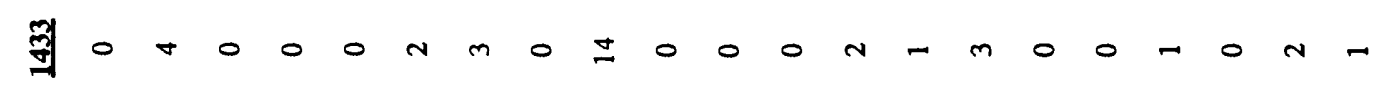

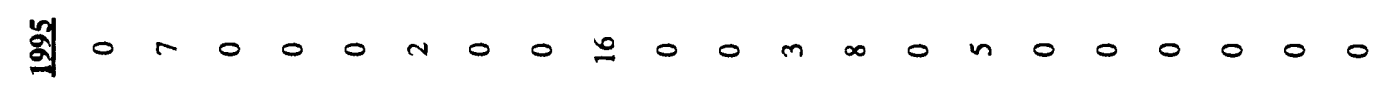

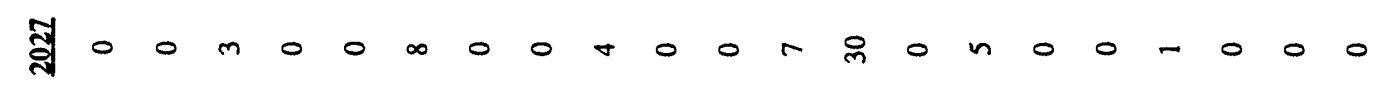

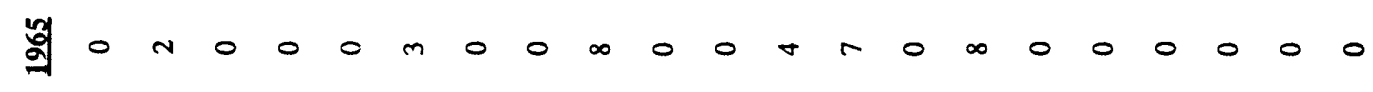

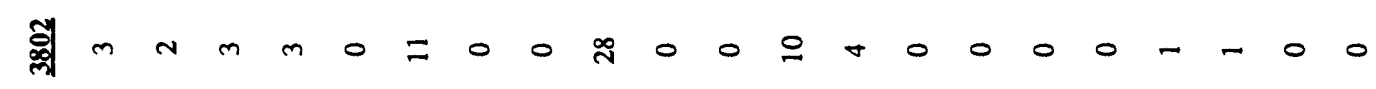

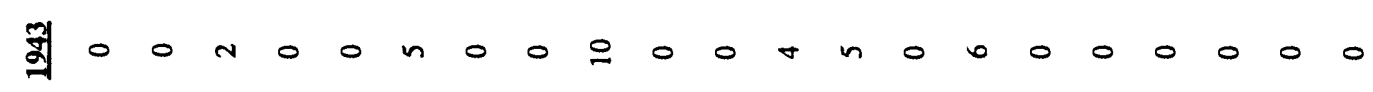
역 $0--00 \pm 00-00 m n 0 m-00000$ 익 $-n n$ n

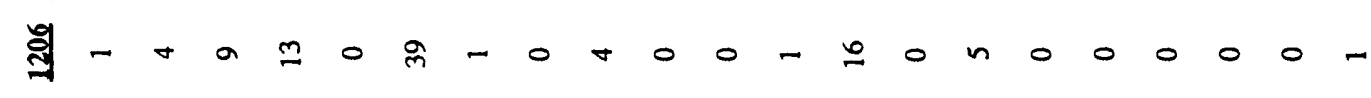

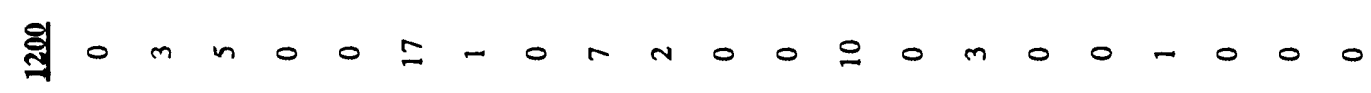

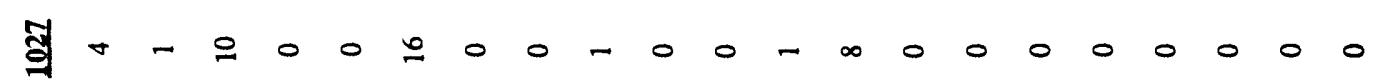

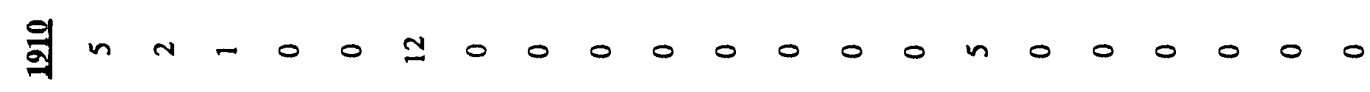

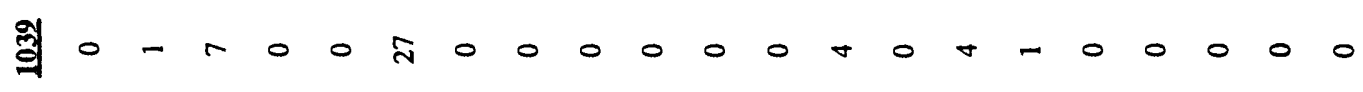
崫

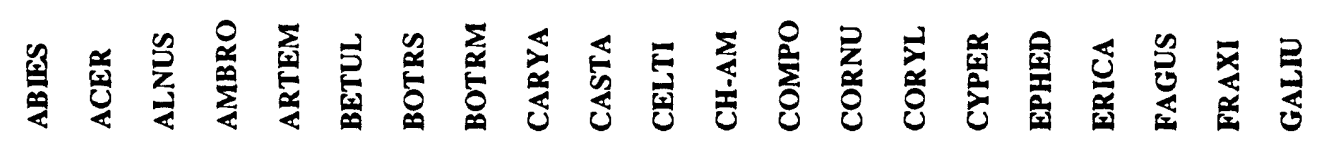




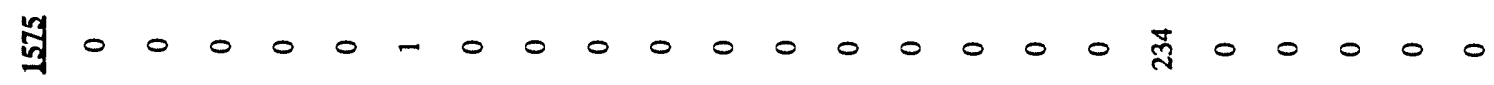

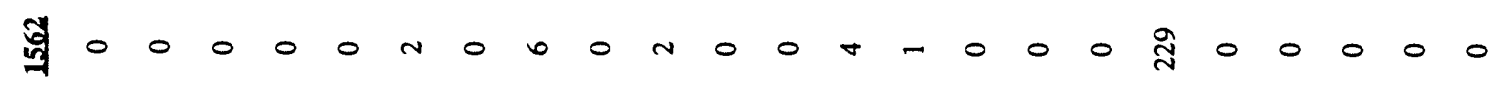

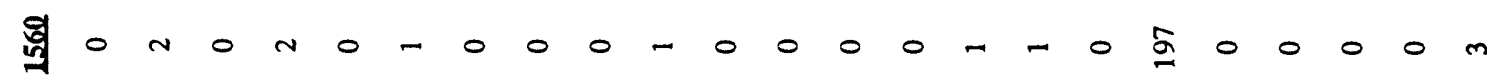

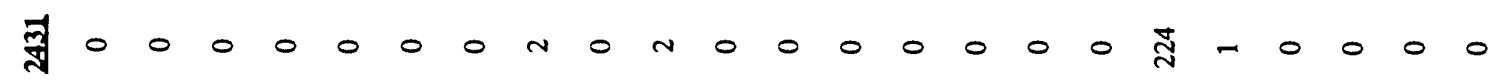

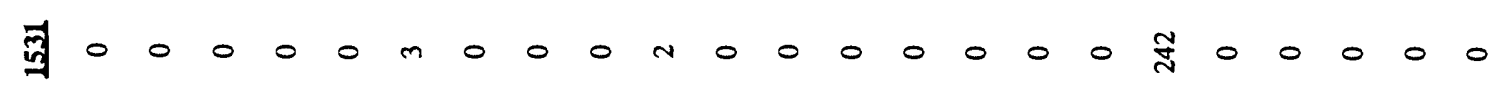

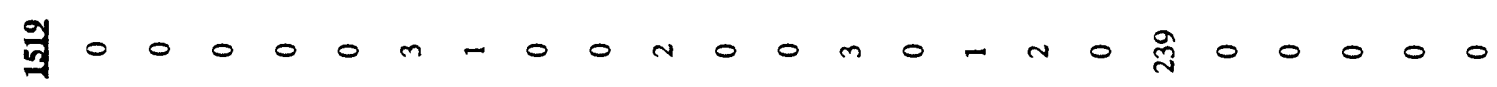

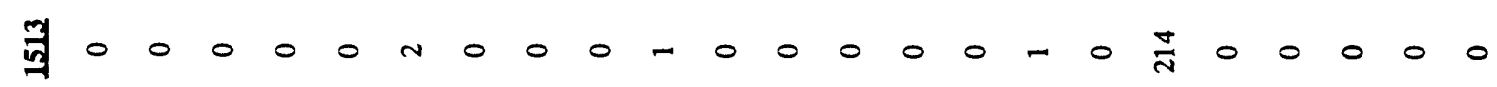

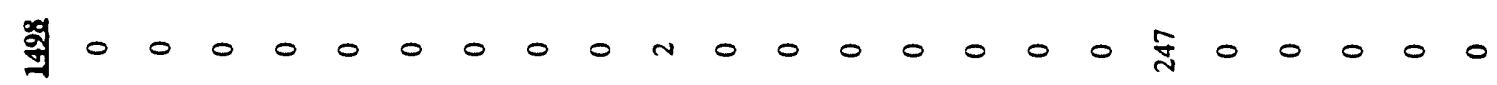

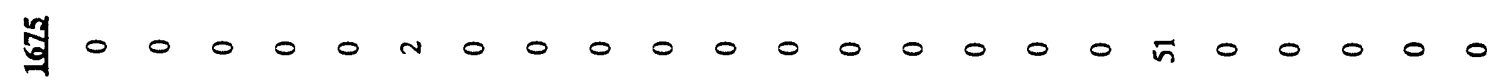

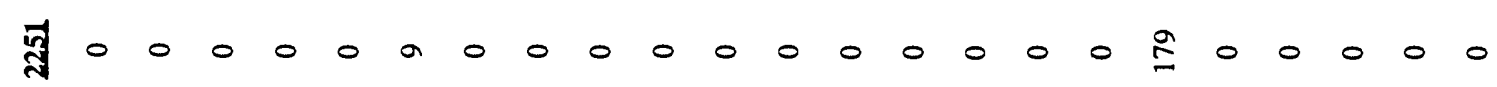

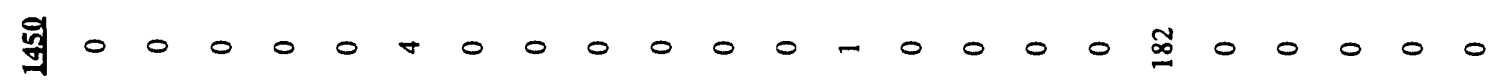
身 $00 m-00-00-00+-000 \leqq 00000$

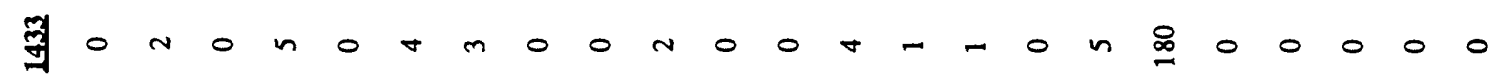

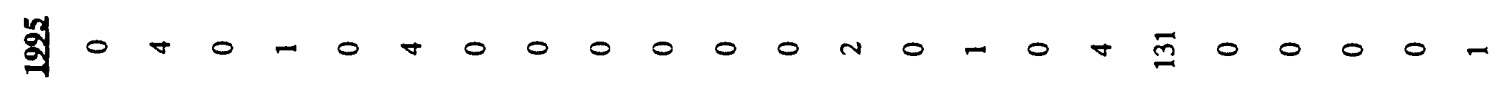

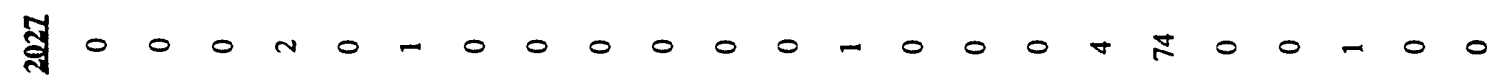
苛 $000+n$ a

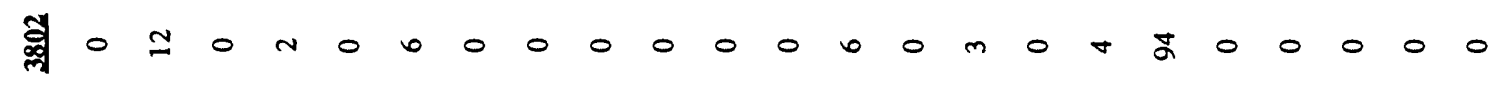

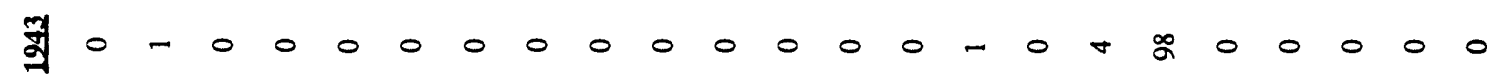
寻 $000000000-000000-0.500000$

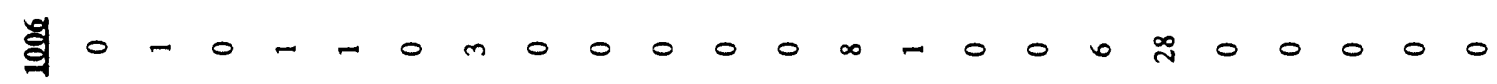

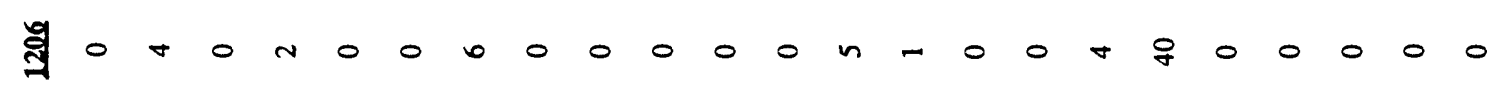

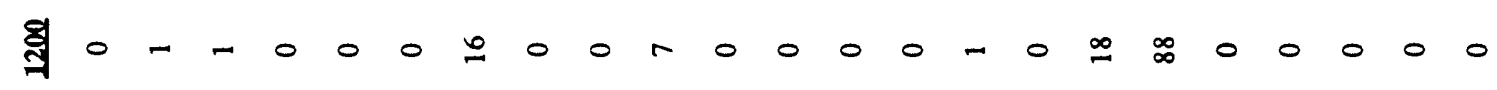

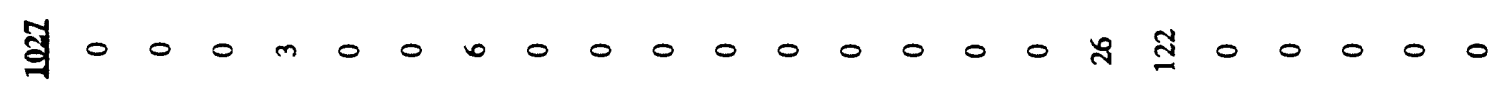

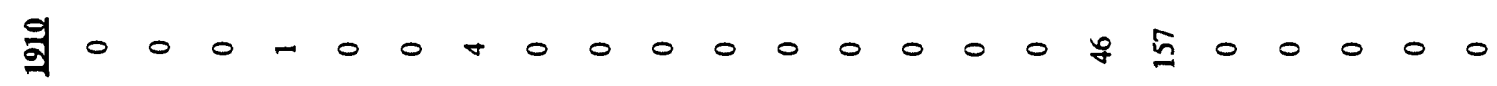

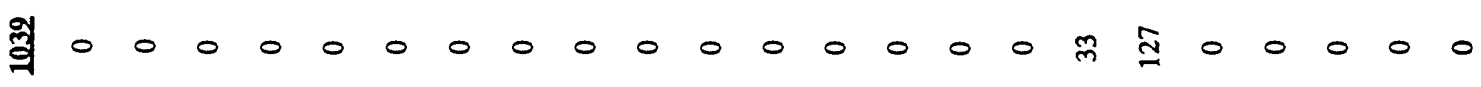

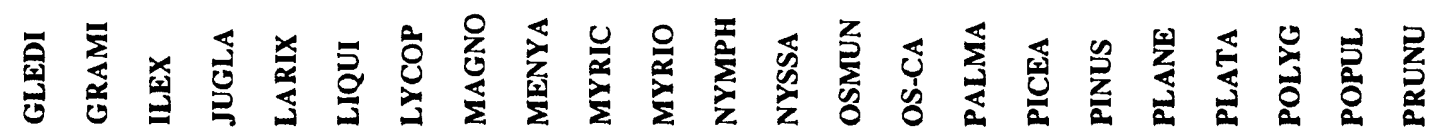




$$
\begin{aligned}
& \text { 匊 }
\end{aligned}
$$

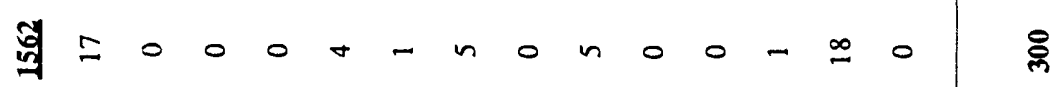

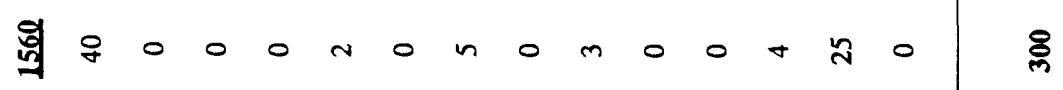

$$
\begin{aligned}
& \text { 司 } \\
& \text { 司 }
\end{aligned}
$$

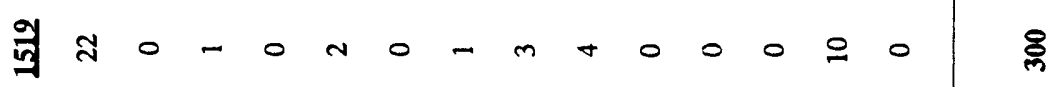

$$
\begin{aligned}
& \text { 霄 } \\
& \text { 粦 } \\
& \text { 舟 }
\end{aligned}
$$

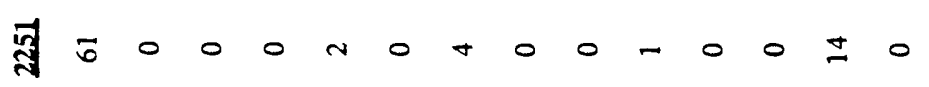

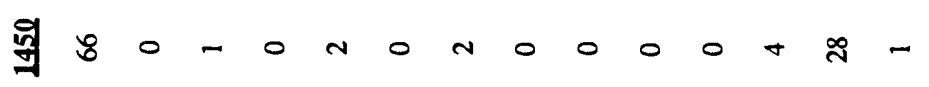

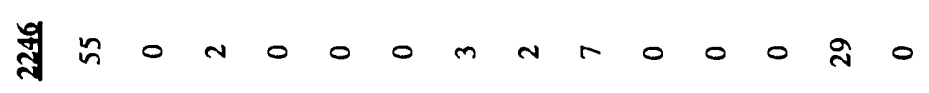

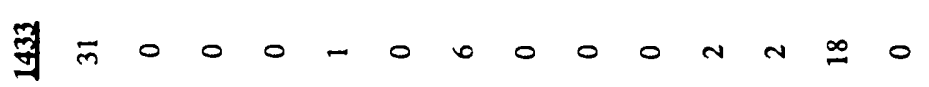

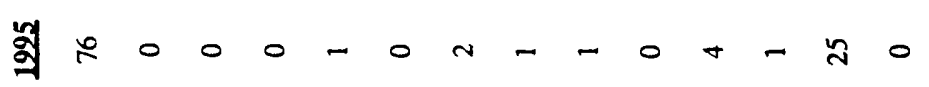

$$
\begin{aligned}
& \text { 本 } \\
& \text { 茟 }
\end{aligned}
$$

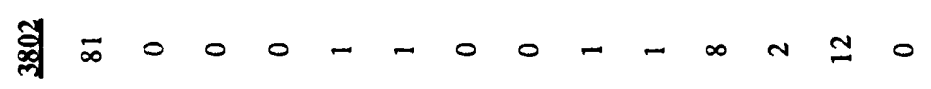

$$
\begin{aligned}
& \text { 祭 }
\end{aligned}
$$

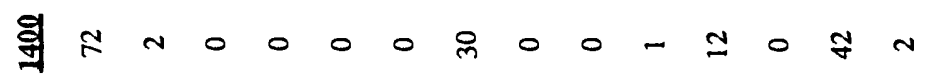

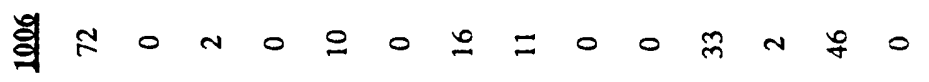

$$
\begin{aligned}
& \text { 寻 } \infty \text { n } 0+-n N O-\infty N \text { - } 0
\end{aligned}
$$

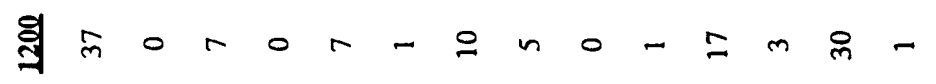

$$
\begin{aligned}
& \text { ปี } \\
& \text { 역ㅇㅇ } 00-0 n-0-\infty 0 \infty 0
\end{aligned}
$$

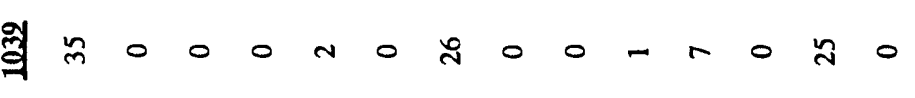

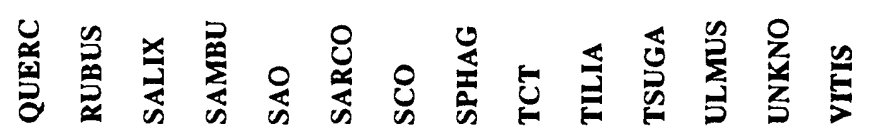

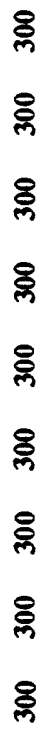

$$
\begin{aligned}
& \text { \& } \\
& \text { \& } \\
& \text { ஓ्ల } \\
& \text { \&్ల } \\
& \text { 윰 } \\
& \text { 윰 } \\
& \text { \& } \\
& \text { ळ్ } \\
& \text { \& } \\
& \text { ळ్లి } \\
& \text { 을 } \\
& \text { \& } \\
& \text { 을 } \\
& \text { \& } \\
& \text { \&్ల }
\end{aligned}
$$

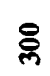

$$
\begin{aligned}
& \text { 랑 }
\end{aligned}
$$




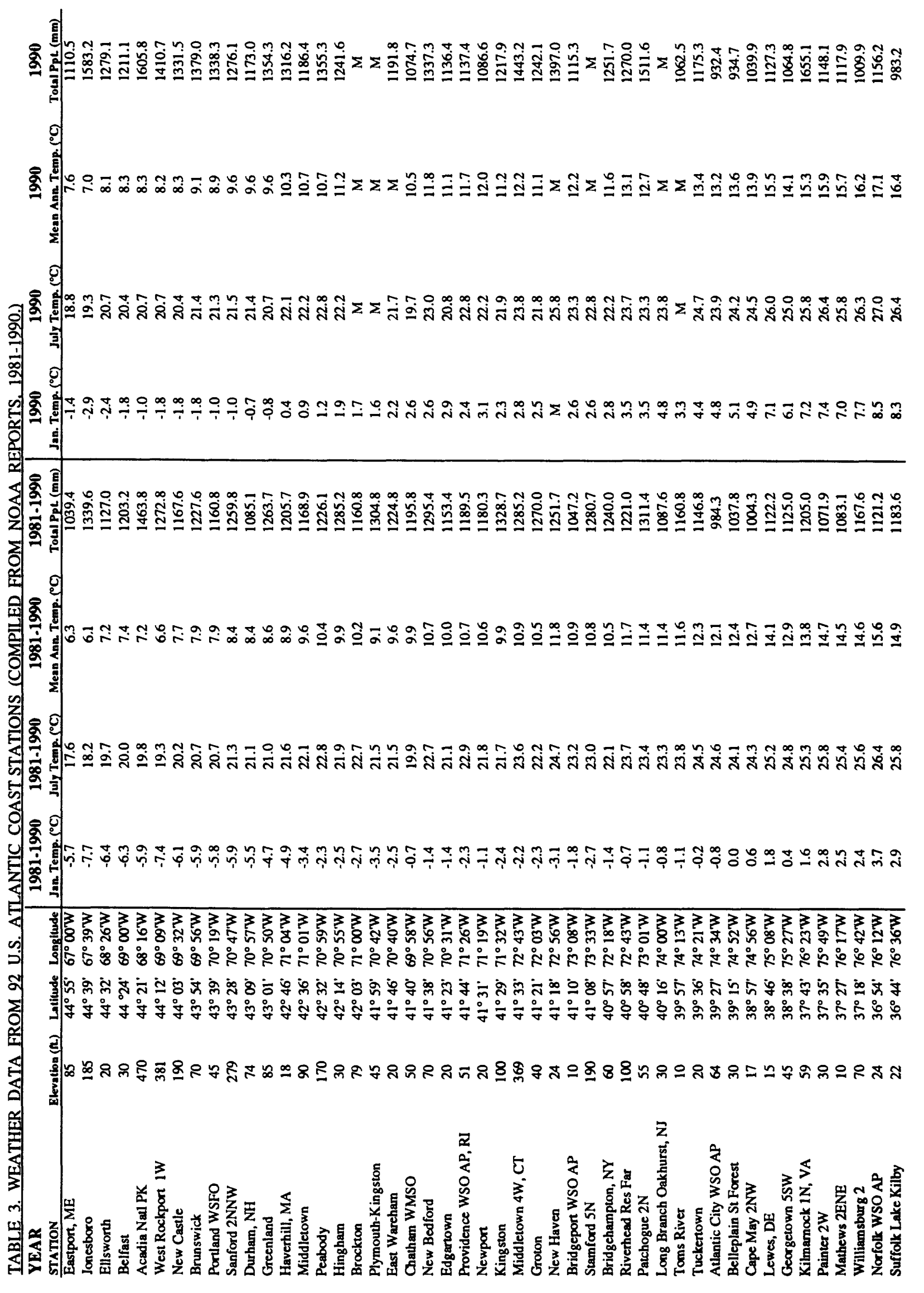




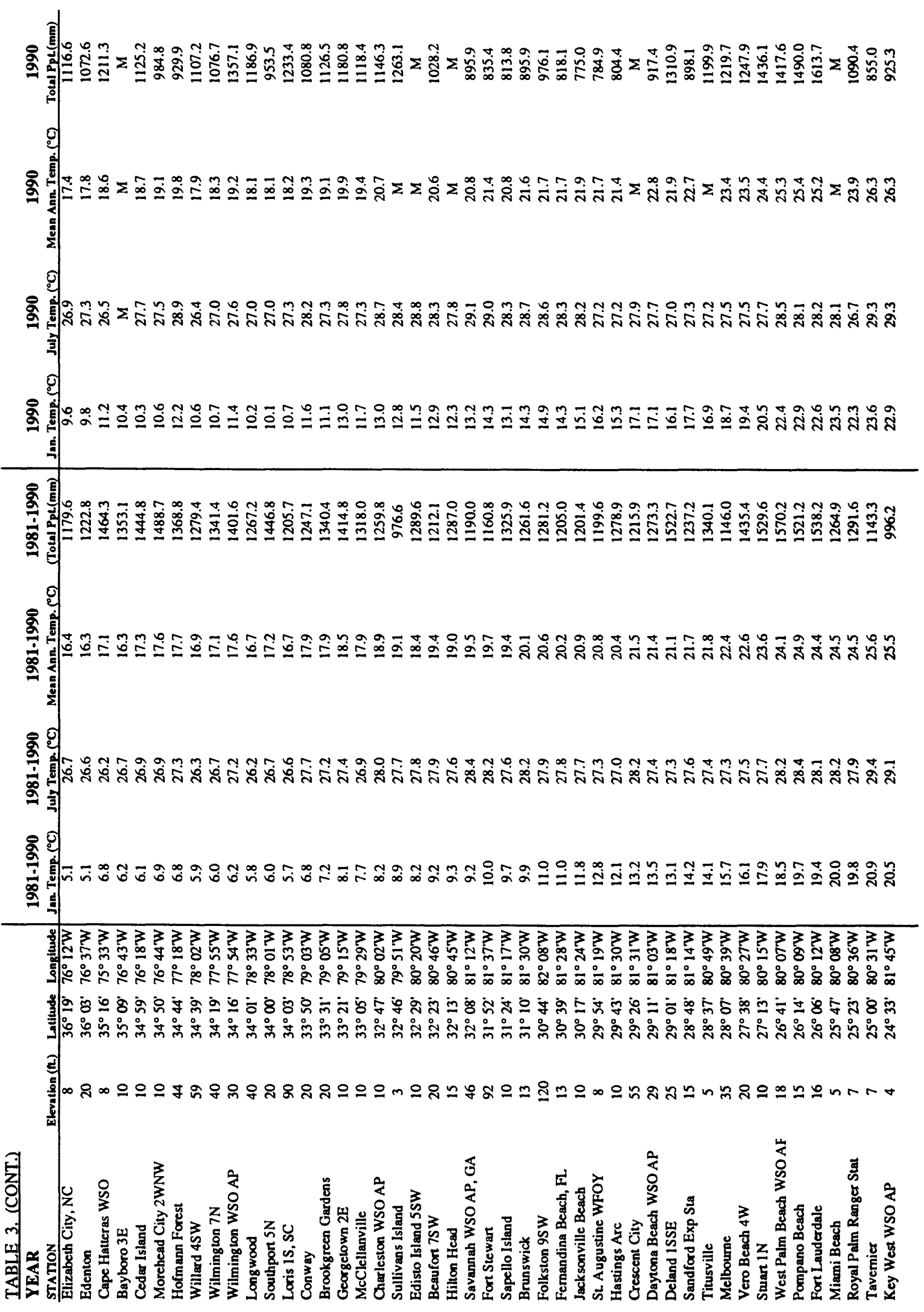




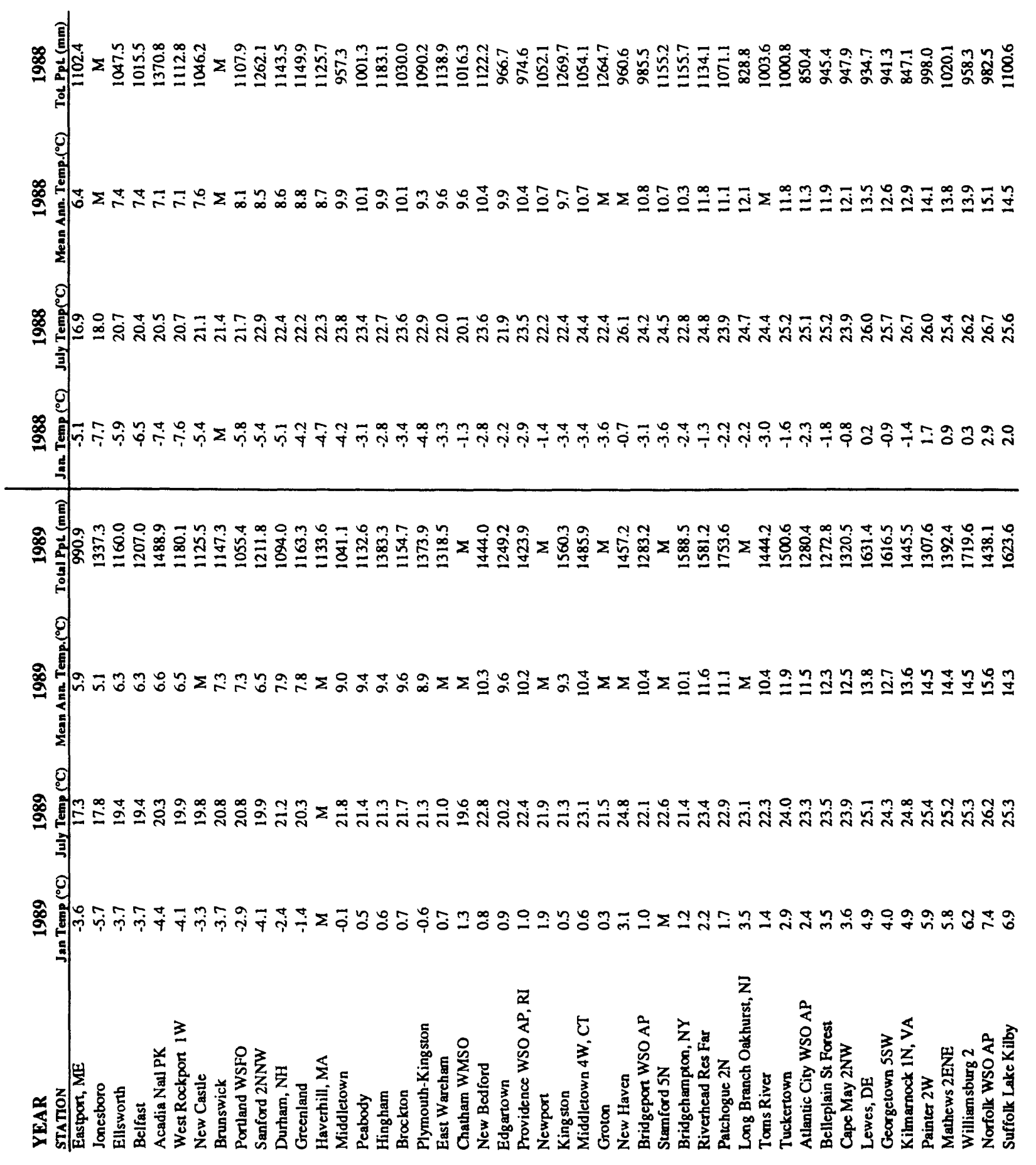




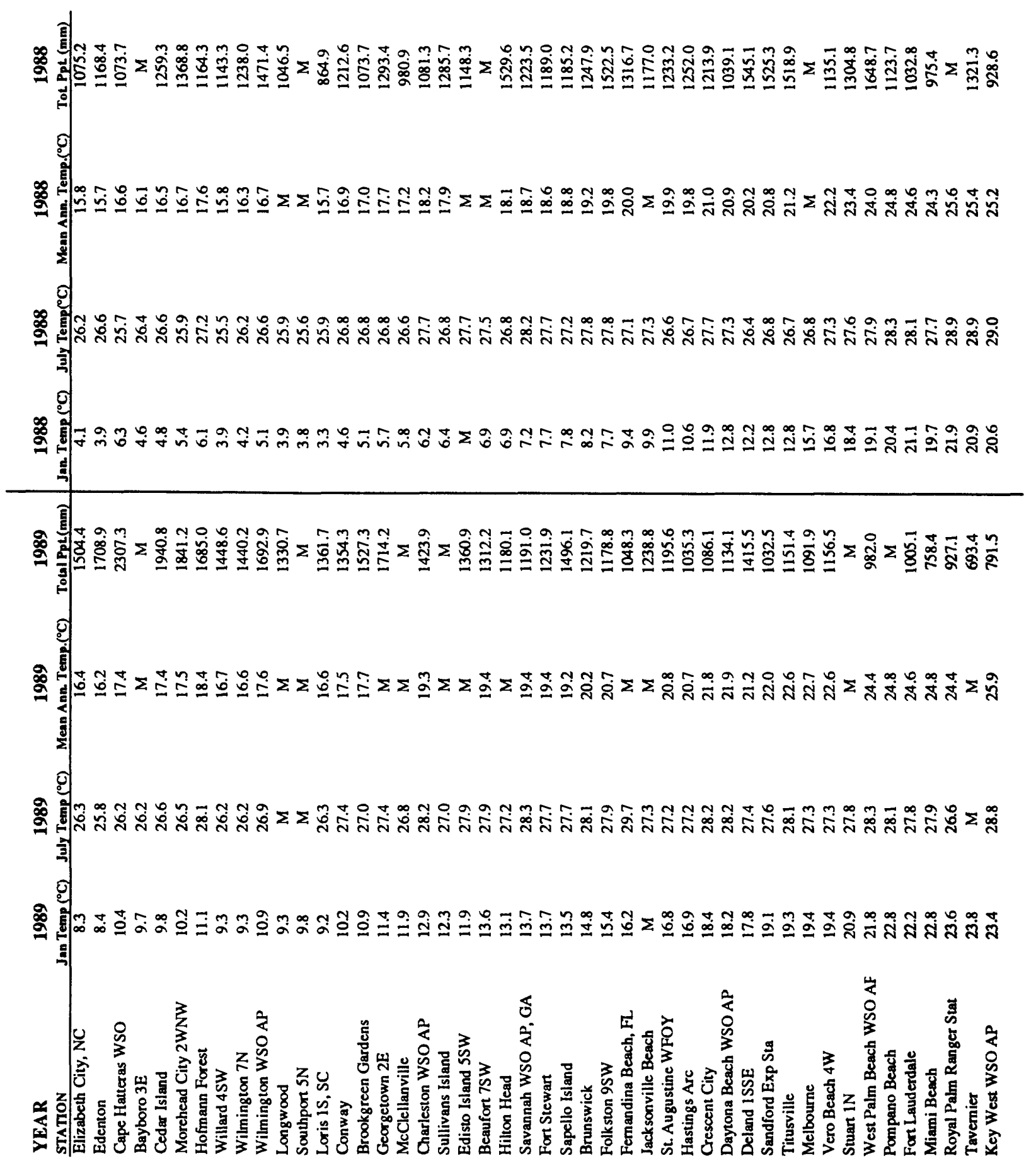




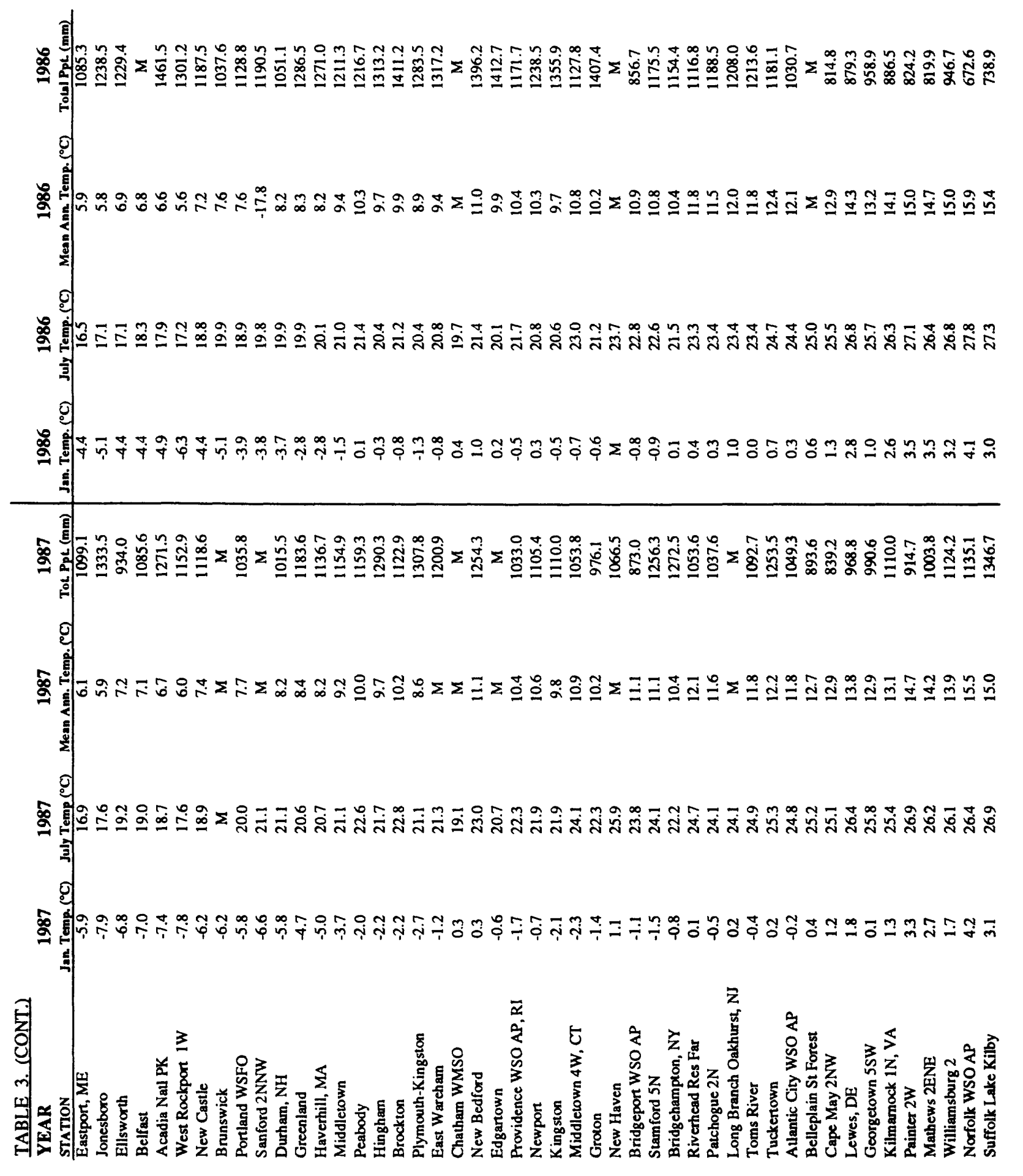




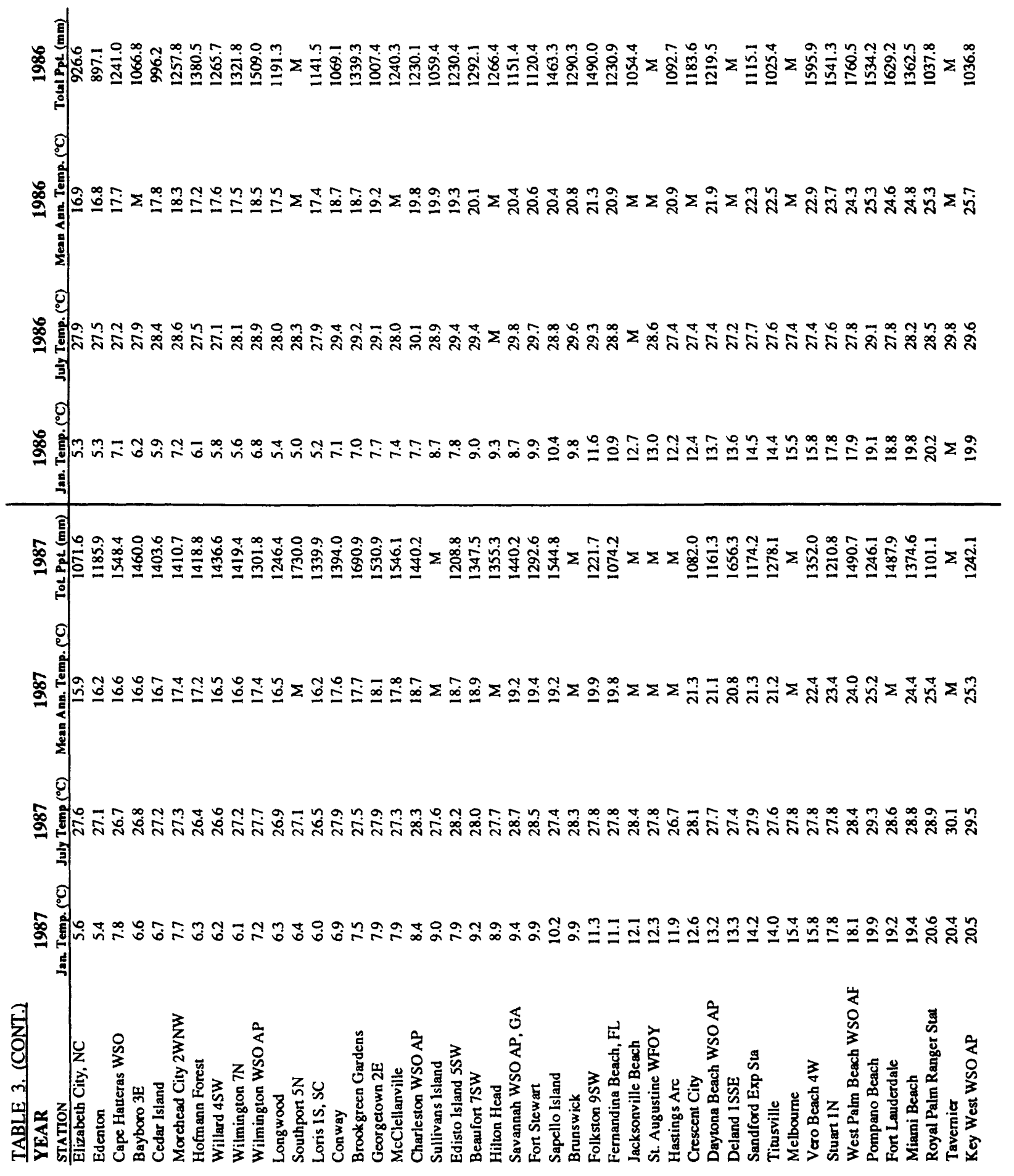




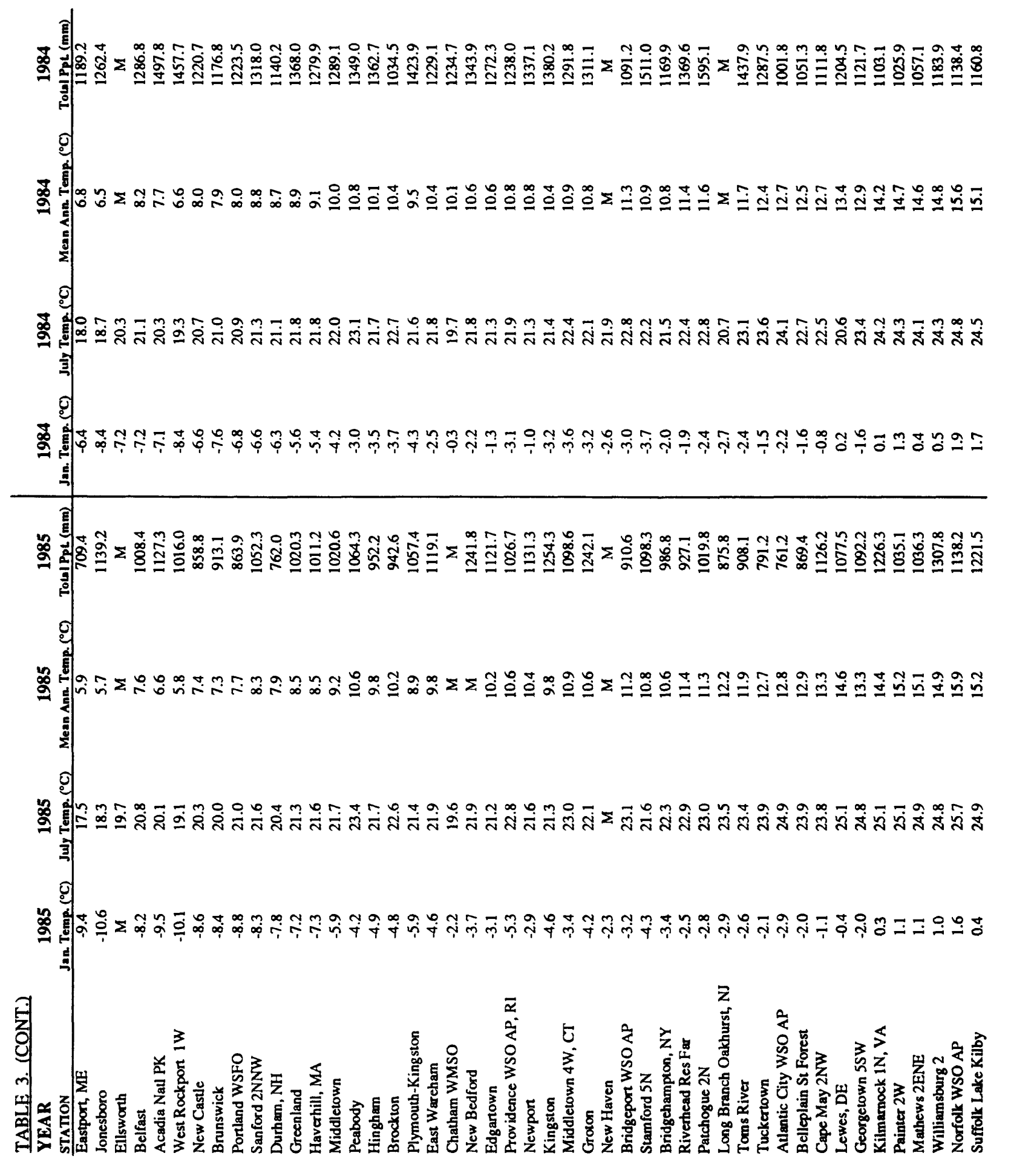




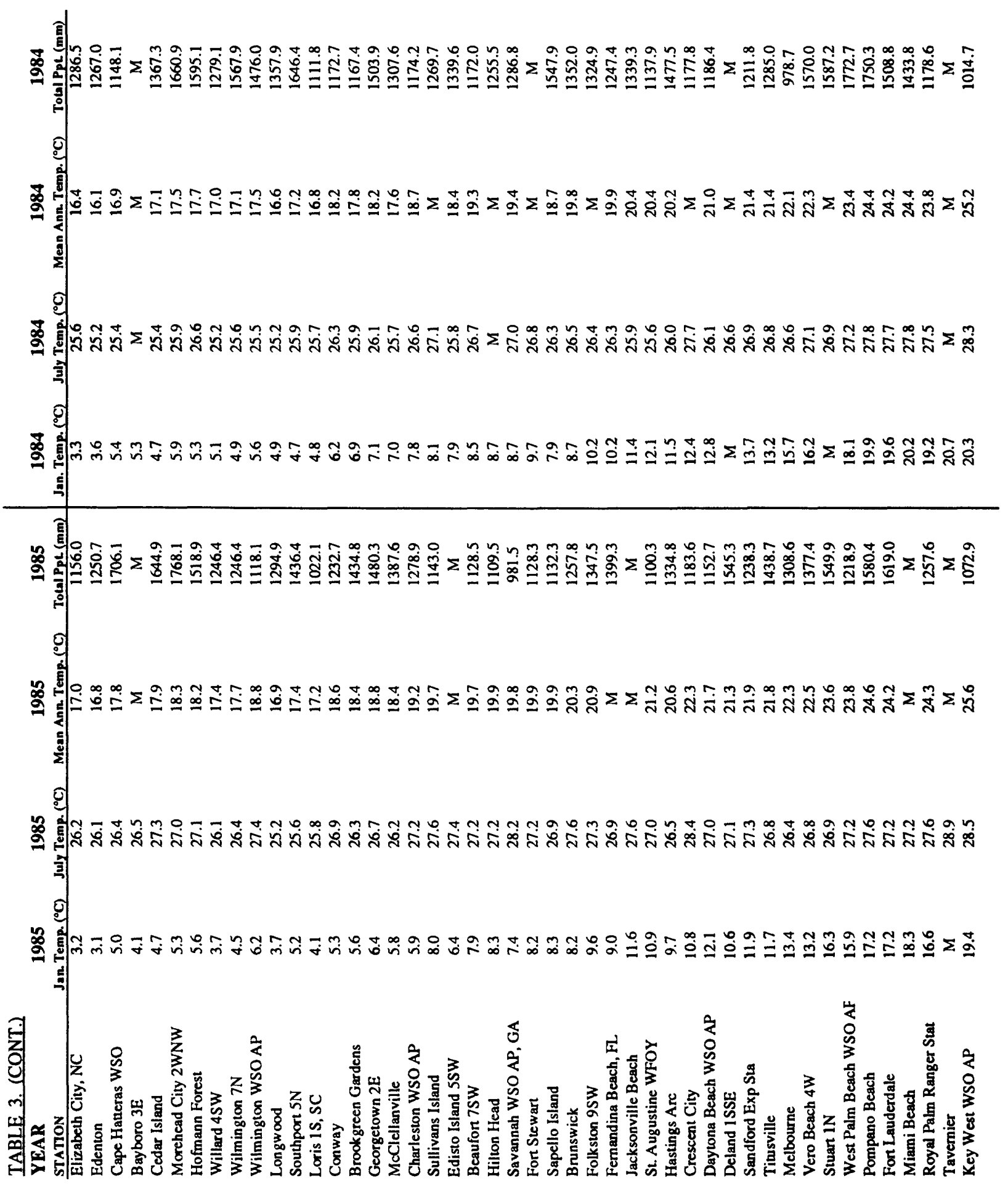




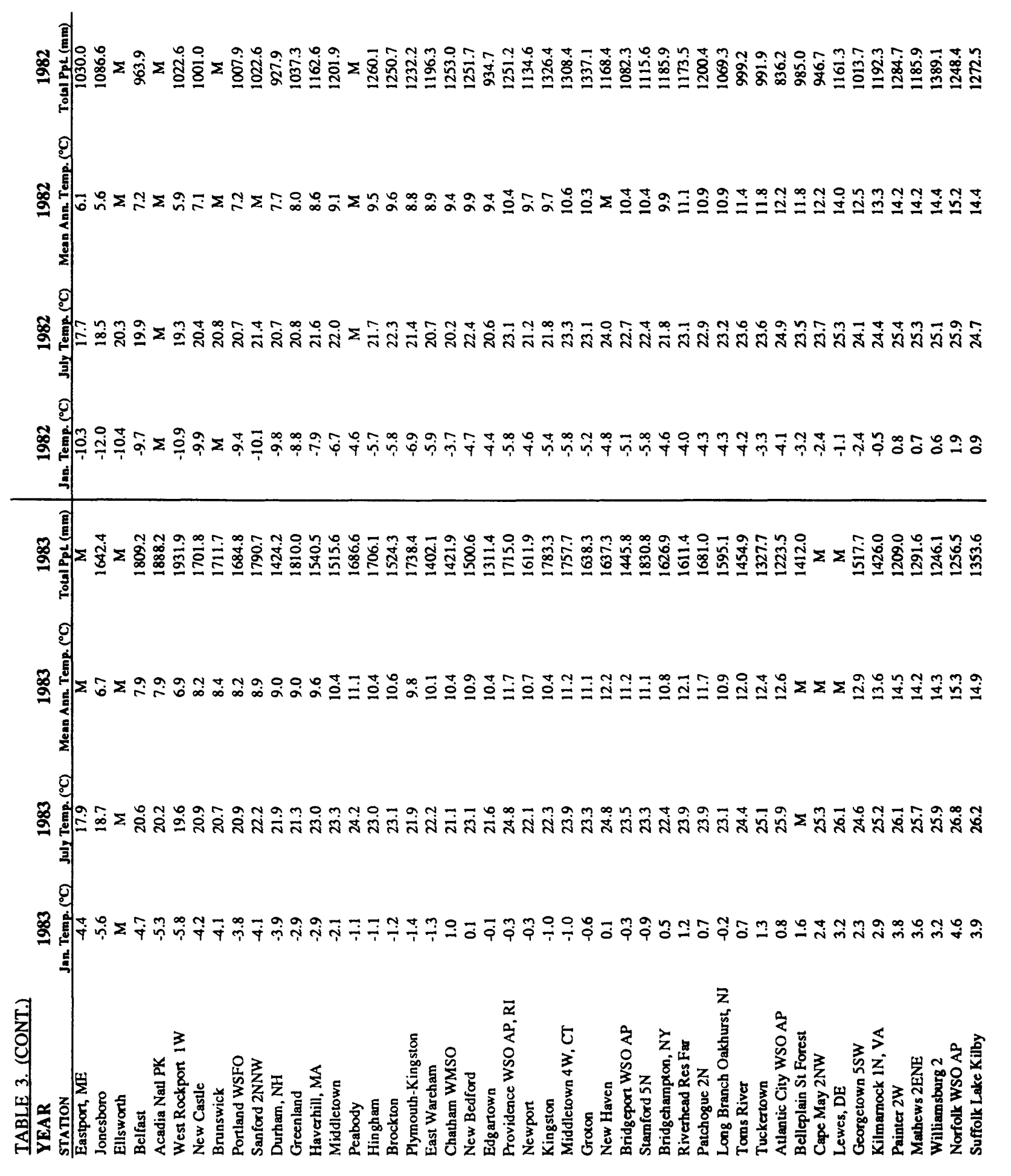




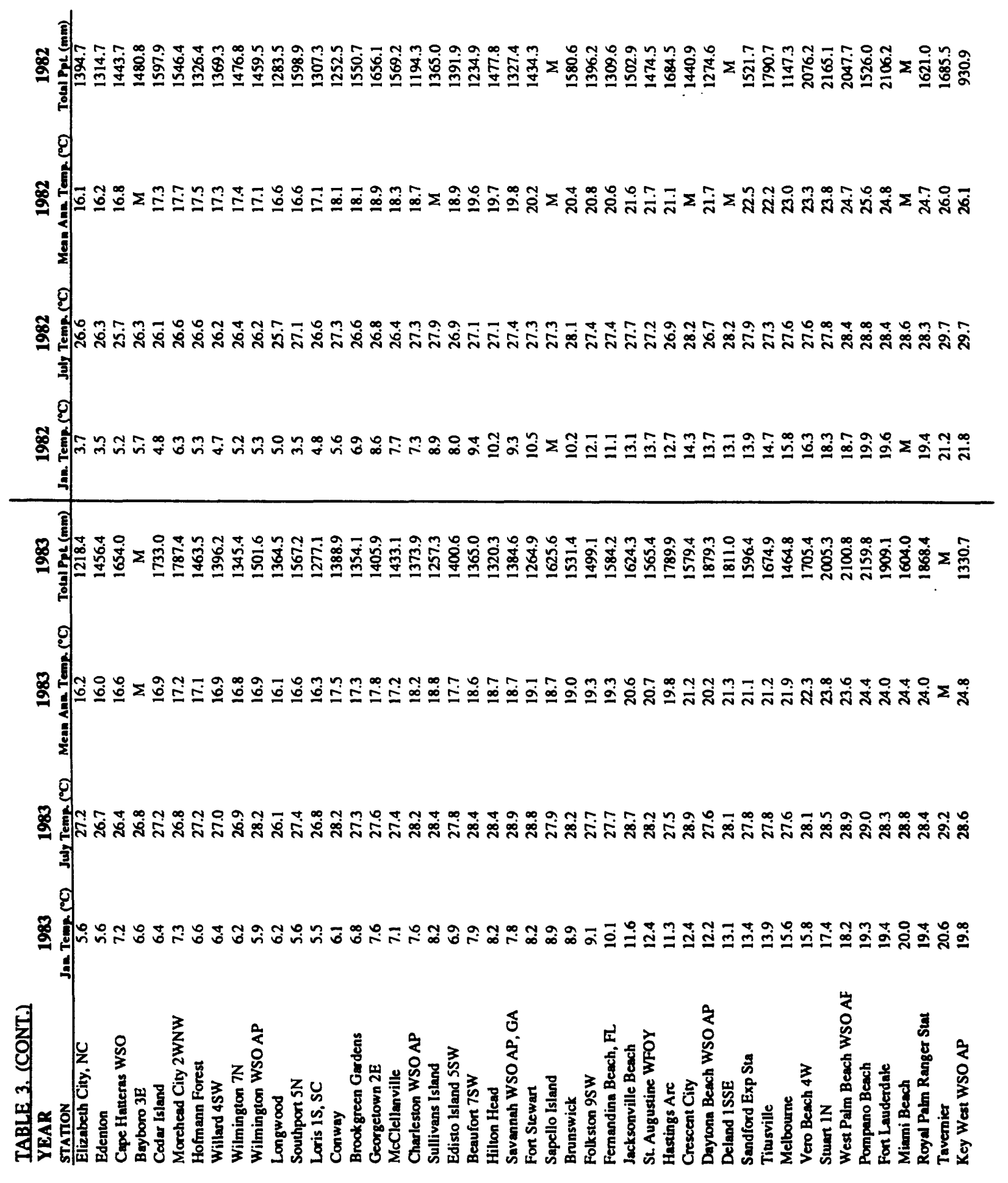




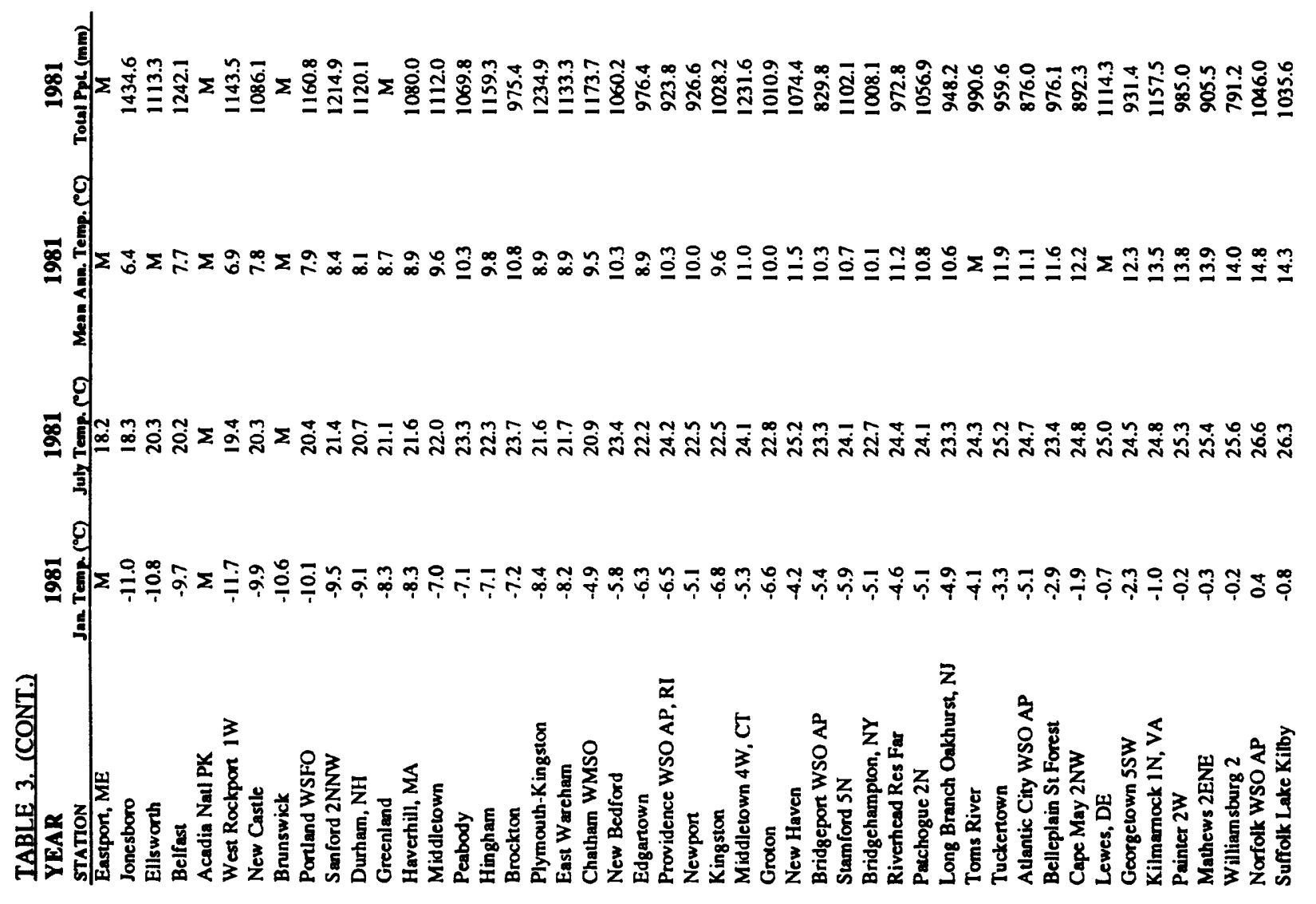




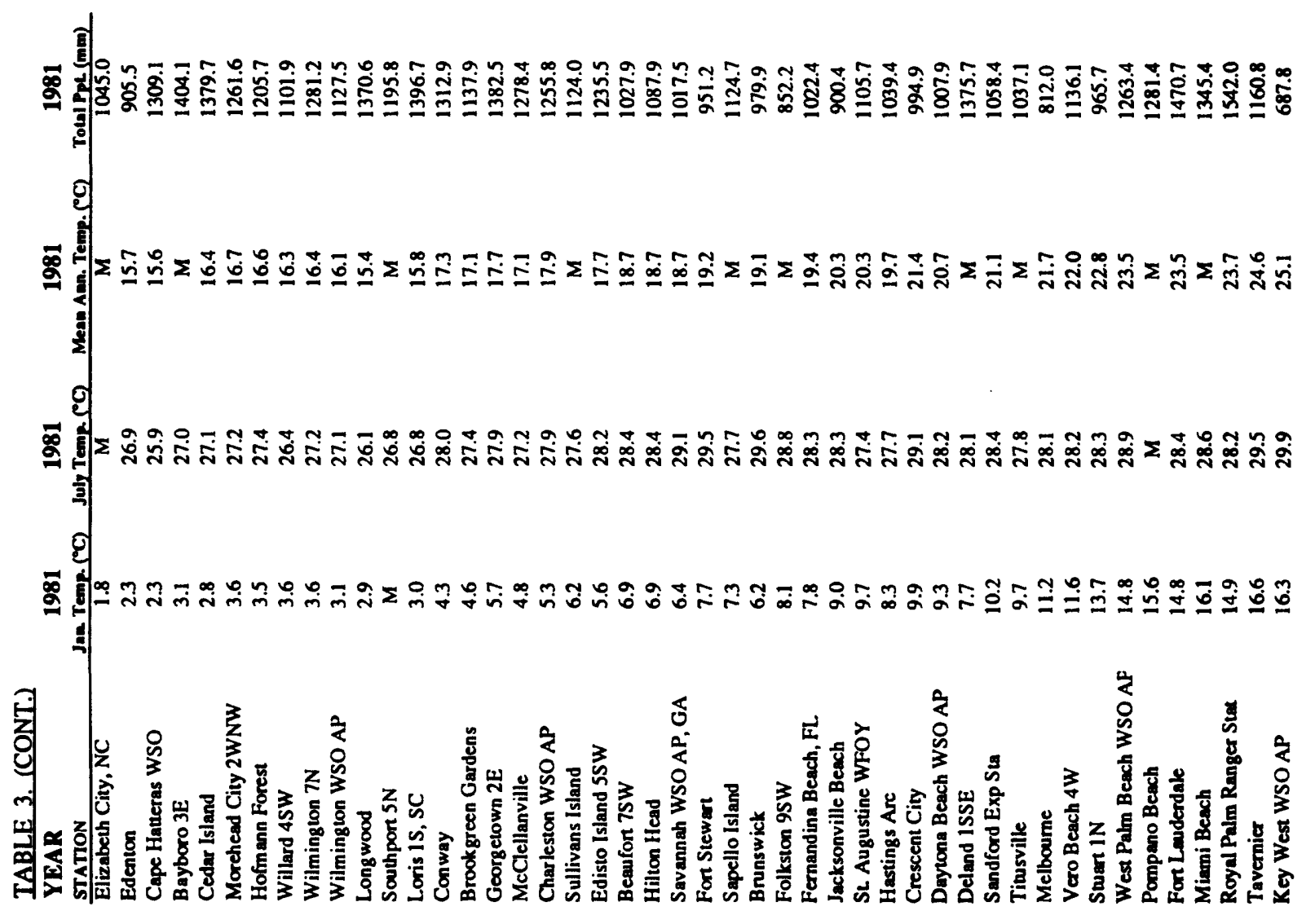

